\title{
KOICA 중장기전략에서의 \\ SDGs 주류화 방안
}

\section{목 차}

I. 서론

II. 국제사회의 SDGs 체제 구축 노력

1. 제3차 UN 개발재원총회 (Addis Ababa Action Agenda, AAAA)

2. UN 개발정상회의

3. UN 기후변화협약 제21차 당사국총회 (COP21)

III. KOICA 중장기전략

1. 수립 배경

2. 주요 내용

IV. KOICA 중장기전략에서의 SDGs 주류화

1. KOICA 중장기전략 3대 핵심과제 및 5 대 브랜드 프로그램

2. 이행 용이성에 따른 SDGs target 분류

3. 세부전략과 이행메커니즘의 조화 방안

\section{V. 결론}




\section{초록(Abstract)}

지난 15 년간 개도국 빈곤퇴치에 기여해온 새천년개발목표(MDGs)의 달성 시한이 2015년 말 로 종료함에 따라, 기존 $\mathrm{MDGs}$ 를 승계하여 향후 15 년을 이끌어나갈 새로운 패러다임인 지속가 능개발목표(SDGs)가 수립되었다. 이에 우리 정부를 비롯한 국제사회는 새로운 SDGs 체제 하 에서 국내외적 환경변화에 발맞추어 새로운 전략 수립의 필요성을 요구받고 있다.

$\mathrm{KOICA}$ 는 새로운 개발체제에 발맞춰 $\mathrm{KOICA}$ 중장기전략을 최근 수립 완료하였다. 본 중장 기 전략은 SDGs 체제의 목표를 존중하는 동시에 우리나라 정부의 국정과제 모두를 고려하여 작성한 종합적인 차원의 기관 전략이다. 이를 바탕으로 $\mathrm{KOICA}$ 는 현재 중장기 전략 내의 세부 과제로서 KOICA 5대 중점분야 및 3대 범분야 각각에 대한 중기전략(2016 2020)을 2016년 6 월 최종완료할 것을 목표로 우선적으로 수립하고 있으며, 이는 기존 KOICA 기존사업을 Post2015 목표를 기준으로 일치 · 통합시키고자하는 'KOICA Post-2015 브랜드화' 작업과 함께 이 루어지고 있다.

그렇다면, $\mathrm{KOICA}$ 중장기전략의 전체적 구성은 어떠하고, $\mathrm{SDGs}$ 차원에서는 어떠한 관련 전략 을 수립하고 있는지에 나누어 살펴볼 필요가 있다. 이에 본 원고에서는 먼저 전략 전체 차원에서, $\mathrm{SDGs}$ 의 비전 및 추진목표, 추진과제 등에 대해 살펴본다. 그리고 난 후 SDGs 차원에서, KOICA 중장기 전략이 SDGs 이행을 위해 설정한 3 대 핵심과제와 5 대 브랜드 프로그램을 소개한다.

이렇듯, $\mathrm{KOICA}$ 는 중장기전략의 전체적인 방향 및 틀을 완성하였으며, 현재는 이를 구성하 는 세부과제들의 세부 전략 및 이행방안을 순차적으로 완성해가고 있다. 이에 KOICA가 앞으로 국내 대표적인 무상원조기관이자 SDGs 논의 및 대응의 선두주자로서의 위치를 지속하기 위해 서는 중장기 전략 내에 설정한 핵심 과제전략 및 이행메커니즘 간의 유기성을 높여 상호간의 적 절한 조화를 꾀함으로써, 궁극적으로 5 대 브랜드 프로그램의 성공적인 이행을 통해 SDGs 달성 에 적극적으로 기여할 수 있어야할 것이다.

\section{I. 서론}

지난 15 년간 개도국 빈곤퇴치에 기여해 온 새천년개발목표 (Millennium Development Goals, MDGs)의 달성 시한(2015년 말)이 도래함에 따라 국제사회는 「세계의 변혁: 2030 지속가능개발의제 (Transforming our world : the 2030 Agenda for Sustainable Development)」에 대한 논의를 진 행해 왔으며, 약 8개월간의 유엔 정부 간 협상결과 지난 2015년 9월 UN개발정상회의에서 최종 문안 
에 합의하게 되었다.

「2030 지속가능개발의제」결과문서는 경제, 사회, 환경 분야를 포괄하는 지속가능개발을 달성하기 위한 「2030 개발의제」의 변혁적 성격을 강조한다. 결과문서를 통하여 MDGs를 승계하는 2015 2030 년간의 글로벌 개발목표로서 지속가능한개발목표(Sustainable Development Goals, SDGs)가 공식 채택되었다. 이번에 공식 채택된 SDGs는 기존에 개도국 중심으로 설정되어 있던 MDGs와 달리 선진 국을 그 대상으로 포함하고 있으며, 경제, 사회, 환경을 통합적으로 고려하는 체제이다. 또한 시민사 회, 민간기업 등 모든 이해관계자의 참여를 촉진하는 포용성을 강조하고 있다.

지속가능발전목표(SDGs)는 2030년까지 빈곤을 종식시키고 지속가능개발을 실현하기 위한 17 개 의 목표와 169 개의 세부목표로 구성되어 있으며, 인간(People), 지구(Planet), 번영(Prosperity), 평 화(Peace), 파트너십(Partnership)을 핵심주제로 모든 인간이 빈곤, 기아, 폭력으로부터 자유롭고 교 육과 보건위생, 안전한 주거와 에너지 접근이 보장되는, 정의롭고 평등한 사회를 비전으로 제시하고 있다. 특히 SDGs는 개도국과 선진국 모두에게 적용되는 보편적 의제, 경제, 사회, 환경을 포괄하는 변혁적 의제, 소외, 취약계층까지 고려하는 포용적 의제이자, 구체적인 이행수단 및 강력한 후속조치 및 평가 시스템과 관련한 내용까지 포함한다.

이렇듯 Post-2030 개발의제는 기존 MDGs가 사회경제적 성장을 강조한 데 비해 지속가능발전을 위한 사회, 경제, 환경적 측면을 균형 있게 고려하고 목표간 연계성을 강화하고 있다. 동시에 지속가 능발전을 위한 선진국과 개도국 공동 목표를 제시해 글로벌 연대에 기반한 광범위하고 보편적인 과제 수립에 중점을 두고 있다.

아울러 SDGs는 다양한 개발과제를 효과적으로 달성하기 위하여 방대하고 야심찬 계획을 이행하기 위한 구체적인 방법과 수단들, 즉 새로운 이행수단(Means of Implementation)을 활용할 것을 강조 하는 동시에, 국내외 다양한 이해당사자가 스스로 책임감과 주인의식을 가지고 가용자원을 총동원함 으로써 개발목표를 달성할 수 있도록 글로벌 파트너십을 구축할 것을 요구한다. 특히, 글로벌 파트너 십 활성화는 목표 달성을 위해 필수적이며, 이는 목표 이행을 지원하기 위한 정부 · 민간 · 시민사회 · 유엔시스템 및 기타 행위자들의 참여 및 모든 가용 자원을 동원함으로써, SDGs 이행을 지원하는 범 지구적 참여를 촉진하고 있다.

이러한 상황에서 $\mathrm{KOICA}$ 는 MDGs 시대가 종료되고 SDGs 시대를 맞이하는 현 시점에서 새로운 개 발체제에 발맞춰 $\mathrm{KOICA}$ 중장기전략을 수립하였다. 중장기전략 내 세부과제로 추진 중인 5 대 중점분 야 및 3대 범 분야 각각에 대한 중기 전략 수립이 2016년 6월까지 최종 완료를 목표로 진행 중에 있으 며, 이는 KOICA Post-2015 브랜드화 작업과 함께 이루어지고 있다. 이에 본 원고에서는 Post-2015 개발의제를 반영한 기관 전체 차원의 $\mathrm{KOICA}$ 중장기전략을 소개함으로써, KOICA가 국내외 개발변 
화 흐름에 발맞추어 어떻게 기관 전략차원에서 SDGs 주류화를 이행하고자 하는지 살펴보고자 한다.

\section{SDGs체제 구축을 위한 2015년 UN 3대 핵심과제}

새천년개발목표(MDGs: Millennium Development Goals)의 달성 시한(2015년 말) 도래함에 따 라, 국제사회는 지난 8개월간 논의해 온 '2030 지속가능개발의제(2030 Agenda for Sustainable Development)'에 대한, 유엔 정부간 협상(2015.1 8월) 결과 최종 문안을 지난 8월 2일 합의하기에 이르렀다. 이에 반기문 UN 사무총장은 개발정상회의가 개발재원총회, 기후변화총회와 함께 2015년 유엔의 3 대 핵심 목표 중 하나임을 강조하였다. 이에 본 부분에서는 SDGs 체제 구축을 위해 올해 핵 심적으로 논의되었던 주요 국제회의에 대해 소개함으로써 SDGs 논의 흐름을 파악하고자 한다(〈그림 1) 참조).

\section{〈그림 1〉2015년 UN의 3대 핵심과제}

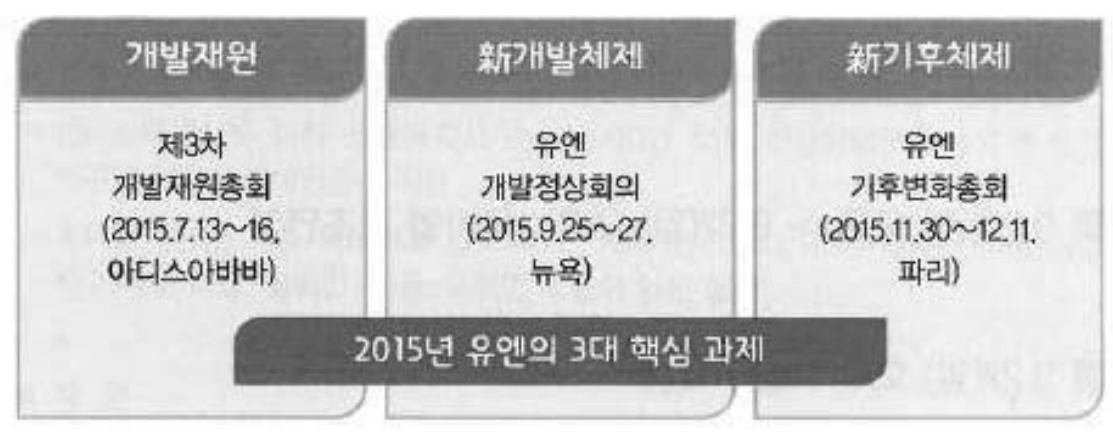

출처: 외교부 (2015)

\section{1. 제3차 UN 개발재원총회}

지난 2015년 7월 13일부터 16일까지 나흘간 에티오피아 아디스아바바에서는 제3차 개발재원총회 가 개최되었으며, 본 회의의 결과문서로서 '아디스아바바 행동의제(Addis Ababa Action Agenda; AAAA)'이 공식 채택되었다. 이번 제3차 개발재원총회는 몬테레이 컨센서스(Monterrey Consensus) 와 도하선언(Doha Declaration)의 이행에 대한 진척상황을 점검하고, SDGs 달성을 위한 재원마련에 새로운 힘을 불어넣을 목적으로 마련되었다(박수영, 오수현 2015). 
몬테레이 컨센서스, 도하선언, 아디스아바바 행동의제에서는 여러 유형의 개발재원에 대한 협력 방안을 기술하고 있다. 개발재원(Development Finance)에 대한 명확히 협의된 정의는 없으나, 포괄 적으로 개발도상국의 빈곤퇴치와 지속가능한 경제사회 발전을 위해 필요한 재원으로 정의될 수 있다. 따라서 개발재원총회(International Conference on Fianncing for Development)는 개발도상국의 빈곤퇴치와 경제, 사회, 환경 개발을 위한 동원가능한 재원이 무엇이며, 이러한 재원의 조달 및 활용 을 위해 수행해야할 노력은 무엇인지를 다루고 있다.

행동의제 문서는 크게 3 부분으로 구성되어 있으며 총 134 항으로 이루어져 있다. 첫 번째 부문 은 총론격인 Post-2015 개발재원을 위한 글로벌 프레임워크(A global framework for financing development post-2015)로서, 이번 개발재원총회의 과제인 몬테레이 컨센서스와 도하선언 이행 상황 점검, $\mathrm{SDGS}$ 달성을 위한 재원마련 및 이행수단 강화, 동 행동계획의 검토 및 후속조치 점검 방안 마련의 필요성, 사회적 협약(social compact)에 대한 약속사항을 기술하고 있다. 본문에서 는 7대 행동분야로서 $\boldsymbol{\Delta}$ 국내공공자원 (Domestic public resources), $\boldsymbol{\Delta}$ 국내외 민간기업 및 재원 (Domestic and international private business and finance), $\boldsymbol{\Delta}$ 국제개발협력(International Development Cooperation), $\mathbf{\Delta}$ 개발동력으로서의 국제무역(International trade as an engine for development), $\boldsymbol{\Delta}$ 부채 및 부채지속가능성(Debt and debt sustainability), $\boldsymbol{\Delta}$ 시스템이슈대응 (Addressing systemetic issues), 솨학기술혁신 및 역량강화(Science, technology, innovation and capacity-building)를 설명하며, 결론에서는 데이터, 모니터링 및 후속조치(Data monitoring and follow-up)에 대해 언급하였다(UN 2015a).

제3차 개발재원총회에서는 다음과 같은 주요성과물을 얻었다. (1) 우리나라도 참여하는 아디스 조 세 이니셔티브(Addis Tax Initiative)를 통해 개도국의 조세역량 강화를 지원하고자 한다. (2) 아디스 아바바 행동의제」에서 출범한 기술 촉진 메커니즘(TFM, Technology Facilitation Mechanism)은 정 부, 시민사회, 민간 부문, 과학계, 유엔기구 및 여타 이해 관계자들이 참여하는 multi-stakeholder간 협력에 기초하고 있다. (3) 다자개발은행이 주도하는 기존 다자협력 메커니즘에 기반한 글로벌 인프라 스트럭처 포럼을 설립함으로써 공여국과 수원국간 글로벌 인프라 간극을 메우고자 한다. (4) UN사무 총장 주재 하에 Post-2015의 이행수단과 개발재원회의 결과물들의 이행상황에 대해 연도별로 보고 를 담당하는 기구간 태스크팀(Inter-Agency Task Team)이 소집된다(UN 2015a).

또한 이번 개발재원총회에서는 SDGs 달성을 위해 다양한 민간 및 공적재원을 활용하여 필요한 투 자를 효과적으로 수행하는 방안을 논의하였다. 본 행동의제는 개발협력의 문제가 국제공적재원활용 의 문제를 넘어 국내 공적 재원 및 국내외 민간재원 동원의 중요성도 강조하고 있다. 또한 ODA의 한 계를 인정하고 대규모 민간재원 동원을 위해 개도국의 투자 수요와 공급간의 간극을 메우고자 하는 방 안을 도모할 것을 강조하고 있다(UN 2015a). 이를 위해 공적개발기관과 민간금융 부문간의 연대 방안 
및 혼합금융, 공적기관의 보증, 개발금융상품의 유동화, 보험의 재난방지 역할 확대 등 새로운 방식이 속속 창안되고 있으며, 유수한 글로벌 기업 및 은행, 펀드들도 국제사회의 큰 흐름에 동참하고 있다.

본 행동계획은 지난 2015년 9월 확정된 SDGs 달성을 위한 이행수단(Means of Implementation) 으로서의 성격을 띠며, 향후 15 년간 개도국과 선진국들이 SDGs 달성에 필요한 재원마련을 위해 협력 해야할 분야들에 대한 내용을 포괄적으로 담고 있다(박수영, 오수현 2015). 특히 본 행동계획에서는 민간분야가 개발의 주요 동인임을 인정하면서 글로벌 기업활동의 연계 필요성을 제시하였다.

\section{UN 개발정상회의}

2015년 9월 25일부터 27일까지 뉴욕에서는 UN 개발정상회의(United Nations Sustainable Development Summit 2015)가 개최되었으며, 본 회의의 결과문서로 「세계의 변혁: 2030 지속가능 개발의제(Transforming our world: the 2030 Agenda for Sustainable Development) 이 공식 채 택되었다. 이번 UN개발정상회의에서는 MDGs를 승계하는 2016 2030년간의 글로벌 개발목표로서 지속가능개발목표(SDGs)를 공식 채택함으로써 SDGs의 성공적 이행에 대한 국제사회의 의지를 확인 하고 각국의 기여 및 추진 계획을 발표하기 위한 목적으로 개최되었다. MDGs를 승계하는 새로운 글 로벌 개발목표로서 공식 채택된 SDGs는 기존에 개도국 중심으로 설정되어 있던 MDGs와 달리 선진 국을 그 대상으로 포함하고 있으며, 경제, 사회, 환경을 통합적으로 고려하는 체제이다. 또한 시민사 회, 민간기업 등 모든 이해관계자의 참여를 촉진하는 포용성을 강조하고 있다.

이번 회의에서는 본회의와 병행하여 총 6 개 세션이 개최되었으며, 국각 대표 및 $\mathrm{NGO}$, 시민사회, 학계, 민간 부문 등 많은 이해관계자들이 참석하였다. 「세계의 변혁: 2015 년 이후 개발의제의 실현 (Transforming the World: realizing the post-2015 development agenda)라는 주제로 개최된 각 세션에서는 다음과 같은 총 6 세션의 주제를 다루었다(〈Box 1〉참조).

\section{〈Box 1〉 상호대화(Interactive Dialogue) 세션 주제}

$\Delta$ (상호대화1) 빈곤 및 기아 종식

$\Delta$ (상호대화2) 불평등 해소, 여성 및 소녀 권익신장 및 포용

$\Delta$ (상호대화3) 지속가능한 경제성장과 변혁 촉진 및 지속가능한 소비,생산 증진

$\Delta$ (상호대화4) 지구보호 및 기후변화 대응

$\Delta$ (상호대화5) 지속가능개발 달성을 위한 효과적이고 책임있는 포용적 제도 구축

$\Delta$ (상호대화6) 글로벌 파트너십 활성화 달성

출처: 외교부 (2015) 
또한 이번 회의에서 주목할 부분은 우리나라 외교부와 UNDP, OECD가 공동 주최하여 「21세 기 新농촌개발전략과 새마을 운동(A New Rural Development Paradigm and the Inclusive and Sustainable New Communities Model Inspired by the Saemaul Undong)」 주제로 한 새마을 운 동 고위급 특별행사를 개최하였다는 점이다. 본 행사에는 $\mathrm{OECD}, \mathrm{UNDP}, \mathrm{KOICA}$ 를 비롯해 한국, 베 트남, 라오스, 페루, 르완다 등 주요정상 및 UN사무총장, World Bank 등이 참석하였다. 본 행사는 새마을운동을 21 세기 개도국 농촌개발에 기여하는 '글로벌 개발 자산'으로 발전 및 확산시킴으로써 $\mathrm{SDGs}$ 이행에 적극 기여하기 위한 프로그램이라는 점에서 그 의의가 있다. 본 새마을운동 고위급 특 별행사에서 주요하게 소개된 국제기구와 한국간의 새마을운동 관련 공동 연구 및 협력사업 사례는 다 음과 같다.

- (한-OECD ㅎ⽄ㅎ농촌개발패러다임 공동연구) 한국은 OECD와 함께 2014년부터 2015년까지 「ㅎ⽄ 농촌개발 패러다임」공동연구를 진행함으로써 새마을 운동의 주요 성공요인을 기초로 21 세기 변 화된 개발환경에 적용가능한 농촌개발 전략 수립을 위한 지침을 제시하고자 하였으며, 본 보고 서는 12 월 발간될 예정이다.

- (한-UNDP 새마을운동 협력사업) 한국은 UNDP와 함께 2014년부터 4년간 '한-UNDP 새마 을운동 협력사업’을 실시함으로써 근면, 자조, 협동에 근거한 새마을운동 이행 지침을 수립하여 지역, 국가 및 글로벌 차원에서 확산, 공유하는 메커니즘을 기획하고 있다. 본 사업을 위해 한국 과 UNDP는 라오스, 미얀마 등 6개국을 시작으로 현장 중심 프로젝트를 실시하고 있다.

이러한 논의를 바탕으로 MDGs와 SDGs간의 차이를 비교해 볼 때, MDGs와 SDGs는 그 개발주 체 및 개발 이슈의 범위에 있어서 주요한 차이를 보인다. 가령, MDGs는 빈곤과 보건, 양성평등, 환 경 등에 한정되어 있는 개발목표로 각 정부를 중점적으로 실천되었다. 하지만 이러한 목표에도 불구 하고 구체적 방안이 부족해 몇몇 목표 달성에 도달하지 못했다는 평가가 있다. 이에 비해 SDGs는 에 너지, 경제성장, 인프라, 지속가능성 등의 새로운 이슈를 추가하였고, 정부 뿐만 아니라 시민, 기업, 정치가, 학자, 이익 집단 등 다양한 전문성을 가진 주체들이 참여하는 것을 목표로 한다. 마지막으로 $\mathrm{MDGs}$ 에 비해 SDGs는 목표별 달성 목표치, 이행방안, 강력한 국제규범을 확립함으로써 훨씬 강력한 적용성을 지녔다고 평가된다(다음 〈표 1〉 참조).

$\mathrm{SDGs}$ 의 주요 특징을 살펴보면 크게 4가지로 볼 수 있다. 우선 SDGs는 개도국과 선진국 모두에게 적용되는 보편적(universal) 의제이자, 기존의 선진국-개도국 간 이분법적 구분을 탈피하고, 인류공 통의 목표를 지향한다는 점에서 개발 패러다임의 근본적인 변환을 요구하는 변혁적(transformative) 의제로 된다. 아울러 저부와 민간을 불문하고 모든 이해관계자들이 참여하는 파트너십(multistakeholder partnership)을 강조함으로써, 소외·취약계층까지 고려하는 포용적(leave no one 


\section{〈표 1〉MDGs와 SDGs 차이 비교}

\begin{tabular}{c|c|c}
\hline 구분 & MDGs (2001 2015) & SDGs (2016 2030) \\
\hline 구성 & 8개 목표 + 21개 세부목표 & 17개 목표 + 169개 세부목표 \\
\hline 대상 & 개도국 & (보편성) 개도국 중심이나, 선진국도 대상 \\
\hline 분야 & 빈곤. 의료. 교육 등 사회 분야 중심 & $\begin{array}{c}\text { (변혁성) 경제성장, 기후변화 등 } \\
\text { 경제 · 사회 · 환경 통합 고려 }\end{array}$ \\
\hline 참여 & 정부 중심 & $\begin{array}{c}\text { (포용성) 정부, 시민사회, 민간기업 등 } \\
\text { 모든 이해관계자 참여 }\end{array}$ \\
\hline
\end{tabular}

출처: 외교부 (2015)

behind) 의제이다. 또한 $\boldsymbol{\Delta}$ 다양한 재정적(ODA, 국내 공적 재원, 민간 재원 등), 비재정적(과학, 기 술, 역량강화 등) 이행수단 동원, $\boldsymbol{\Delta}$ 글로벌 파트너십 활성화, $\boldsymbol{\Delta}$ 다층적(국가-지역-글로벌) 후속조치 및 평가 체계 수립 등 구체적인 이행수단 및 강력한 후속조치와 평가시스템에 관련한 내용까지 포함 하고 있다. 이러한 특징들을 바탕으로 SDGs는 총 17 개의 개발목표와 169 개의 세부목표로 구성되어 있다. 17 개 주요 목표는 다음과 같다.

\section{〈Box 2〉SDGs 17개 목표}

(1) 모든 곳에서 모든 형태의 빈곤 종식

(2) 기아 종식, 식량안보와 영양 개선 달성 및 지속가능한 농업 진흥

(3) 모든 연령층의 모든 사람을 위한 건강한 삶 보장 및 복리 증진

(4) 포용적이고 공평한 양질의 교육 보장 및 모두를 위한 평생학습 기회 증진

(5) 양성평등 달성 및 모든 여성과 소녀의 권익 신장

(6) 모두를 위한 물과 위생 이용가능성 및 지속가능한 관리 보장

(7) 모두를 위한 저렴하고 신뢰할 수 있으며 지속가능하고 현대적인 에너지에 대한 접근 보장

(8) 모두를 위한 지속적이고 포용적이며 지속가능한 경제성장 및 완전하고 생산적인 고용과 양질의 일자리 증진

(9) 회복력 있는 사회기반시설 구축, 포용적이고 지속가능한 산업화 증진 및 혁신 촉진

(10) 국가 내 및 국가간 불평등 완화

(11) 포용적이고 안전하며 회복력 있고 지속가능한 도시와 거주지 조성

(12) 지속가능한 소비 및 생산 양식 보장

(13) 기후변화와 그 영향을 방지하기 위한 긴급한 행동의 실시

(14) 지속가능개발을 위한 대양, 바다 및 해양자원 보존 및 지속가능한 사용

(15) 육상 생태계의 보호, 복원 및 지속가능한 이용 증진, 산림의 지속가능한 관리, 사막화 방지, 토지 황폐화 중지와 회복 및 생물다양성 훼손 중지 
(16) 모든 수준에서 지속가능개발을 위한 평화롭고 포용적인 사회 증진 모두에게 정의에 대한 접근 제공 및 효 과적이고 책임 있으며 포용적인 제도 구축

(17) 이행수단 강화 및 지속가능개발을 위한 글로벌 파트너십 강화

출처: 김지현 (2014)

\section{나. 이행수단과 글로벌파트너십}

글로벌 파트너십을 강화함으로써 SDGs의 효과적인 이행을 지원하기 위해 정부, 민간, 시민사회, $\mathrm{UN}$ 시스템 등 다양한 행위자들이 참여함으로써 모든 가용 자원을 동원할 필요가 있다는 배경에서 주 목받기 시작하였다. 이행수단(means of Implementation, MoI)이란, SDGs의 방대하고 야심찬 계획 을 이행하기 위한 구체적인 방법과 수단들을 의미한다. 즉, 국내외 다양한 이해당사자가 스스로 책임 감과 주인의식을 가지고 가용자원을 총동원함으로써 개발목표를 달성할 수 있도록 글로벌 파트너십을 구축할 것을 요구한다(UN 2015b).

글로벌 파트너십 활성화는 목표 달성을 위해 필수적이며, 이는 목표 이행을 지원하기 위한 정부 · 민간 · 시민사회 · UN시스템 및 기타 행위자들의 참여 및 모든 가용 자원을 동원함으로써, SDGs 이행 을 지원하는 범지구적 참여를 촉진하고 있다.

특히 「2030 지속가능개발의제」의 필수적인 일부인 「아디스아바바 행동의제」는 「2030 개발의제」의 이행수단 관련 세부목표들을 지원 및 보완하면서 상호 연계성을 갖고 있으며, 두 의제 모두 지속가능 개발을 위한 글로벌 파트너십 활성화를 통한 이행수단 동원이 가장 중요하다는 점을 강조하고 있다.

\section{UN 기후변화협약 제21차 당사국총회(COP21)}

‘지구 역사상 가장 중요한 2주일’로 불리는 제21차 유엔기후변화협약 당사국총회1)(COP21)가 프랑 스 파리에서 지난 11 월 30 일부터 12 월 11 일까지 2주간 개최되었다. 이번 회의를 통해 1997 년 교토의 정서 이후 18년 만에 '신(新)기후(氣候)체제'가 구축되었다. 교토의정서가 산업화 과정에서 온실가스를 많이 배출한 선진 38개국에 국한해 감축의무를 부여한 반면, 2020년 이후 신(新)기후(氣候)체제에서 는 선진국과 개도국, 극빈국 등 전 세계 모든 국가가 감축의무를 함께 지게 된다.

1) 당사국총회는 유엔기후변화협약의 최고 의사결정 기구로서 매년 세계 각국의 환경분야 장관급 인사들이 모여 온실 가스 감축, 기후변화 적응 등을 논의하고 협약의 이행상황을 정기적으로 검토 및 이행을 촉진하고자 개최되는 국제 회의이다. 
이번 COP21 총회가 특히 주목을 받는 이유는 교토의정서 ${ }^{2)}$ 공약이 종료될 예정인 2020년 이후 적 용될 신 기후체제에 대한 협상을 타결 짓고, 합의문 채택을 목표로 하고 있기 때문이다. 즉 선진국 중 심으로 온실가스 감축의무를 부과했던 교토의정서의 후속체제인 '신(新)기후(氣候)체제'를 2015년 말 까지 협상을 마무리 짓고, 합의문을 채택하는 것을 목표로 하며, 오는 2020 년 이후 발효될 것으로 예 상된다.

우선 이번 파리 총회에서는 각국이 제시한 감축방안에 법적 구속력, 개발도상국 온실가스 배출을 줄이기 위한 선진국의 대규모 재정지원방안 등이 주요 의제로 다뤄졌다(UN 2015c). 아울러 과거와 달리 각국의 책임회피를 막기 위해 정상급 회담을 먼저 진행하고 그 결과에 따라 구체적인 실천방안 을 합의한다는 원칙도 있다.

또한 이번 총회에서는 올 한해 각국이 제출한 신기후체제 기여방안(INDC)을 토대로, 앞으로 주기 적으로 감축목표를 갱신하고 이행을 점검하기 위한 절차 등이 결정되었다(UN 2015c). 그간 협상과정 에서 각국은 신규 감축목표를 포함한 각국의 기여방안을 파리 총회에 앞서 제출하기로 합의한 바 있 으며, 이에 따라 지금까지 170 여개 당사국이 UN에 제출을 완료하였다. 우리나라도 2030년 배출전망 치(BAU) 대비 $37 \%$ 감축목표와 함께 국가 기후변화 적응정책 등을 포함한 기여방안을 지난 6월 30 일 $\mathrm{UN}$ 에 제출한 바 있다. 지금까지 각국이 제출한 감축목표를 합하면 전세계 온실가스 배출량의 $90 \%$ 이 상에 달하는 목표치로, 역사상 최대 규모의 국제적인 온실가스 관리 기반이 마련되는 것이라 평가할 수 있다. 교토의정서의 경우, 미국, 캐나다, 일본, 러시아, 뉴질랜드 등 주요국들이 불참하면서 그 관 리대상이 전세계 온실가스 배출량의 $20 \%$ 에도 미치지 못한다는 지적을 받아왔다.

우리나라에 의무적인 감축책임이 부과되지 않았던 교토의정서와 달리, 신(新)기후(氣候)체제에서 는 우리나라를 포함하여 모든 국가들이 선진국과 개도국 구분없이 감축에 참여하게 되어 국제적인 기 후변화 대응의 새로운 전기가 마련될 것으로 전망된다. 다만, 온실가스 감축목표 설정 방식에 있어 국 가별 의무감축분을 하향식으로 할당하였던 과거 방식에서 벗어나, 각국이 다양한 국가별 상황을 반영 하여 스스로 감축목표를 결정할 수 있도록 허용하는 유연한 접근 방식을 채택할 것으로 예상된다.

각국의 기여방안 제출을 통한 동참의지 표명 이 외에도 최근 미국, 중국, 프랑스 등 주요국에서 신

2) 교토의정서(Kyoto Protocol)이란, 유엔기후변화협약의 실질적인 이행을 위해 1997년 제3차 유엔기후변화협약 당사 국총회에서 채택된 의정서로서, 선진국과 시장경제전환국가에 대해 2008 2012년간 1990년 대비 평균 5\% 이상의 온실가스 감축 의무를 부과, 2005년 2월 발효하였으며, 우리나라는 2002년 11월 비준함.

3) 각국이 정하는 기여방안(INDC: Intended Nationally Determined Contribution)이란 2013년 11월 폴란드 바르샤바에 서 개최된 제 19 차 유엔기후변화협약 당사국총회의 결정에 따라, 협약의 이행을 위한 각국의 감축목표, 적응정책 등 각국이 스스로 결정하여 유엔에 제출하는 기여방안을 말함. 
기후체제 출범을 위한 강력한 정치적 의지를 보였다. 그러나 각국의 기여방안에 대한 국제법적 구속 력, 개도국의 기후변화 대응을 지원하기 위한 재정지원 계획 등 일부 쟁점에 대해서는 주요국간 의견 이 대립하고 있어 협상 막바지까지 격론을 벌였다.

본 회의에 우리 대표단은 환경부, 외교부, 산업통상자원부 등으로 구성된 정부대표단과 산업계, 시 민사회 관계자 등이 참석하였으며, 우리대표단은 선진국과 개도국간 중재역할을 통해 협상타결을 위 해 적극 노력하는 한편, 주요국과의 양자협의 등을 통해 주요쟁점에 대한 해결책을 모색하고자 한다. 또한 총회기간 동안 현지에서 한국관(파빌리온)을 운영하여 온실가스배출거래제 도입, 국가 기후변화 적응 대책 수립, 국가 온실가스 통계 관리체계 구축 등 우리나라 기후변화 대응경험과 노력을 국제사 회에 적극적으로 알리는 활동을 하였다.

기후변화 대응은 협의의 개발협력을 넘어 창의적이고 혁신적인 방법을 통한 대응과 국제적 연대를 요구한다(UN 2015c). 이러한 과제들은 특정분야에 국한되지 않는 다분야적 접근을 요구하고 있으며, 공여국 선진국 모두의 적극적인 참여가 필요하다. $\mathrm{CO} 2$ 배출을 줄이는 경제에너지 패러다임의 전환에 서부터 기후변화에 취약한 개도국 및 빈곤층의 대응력을 높이는 것은 막대한 재원동원 뿐만 아니라, 정치적 결단과 사회적 합의, 기술개발 등 다양한 노력이 필요하며, 이를 위한 선진국들의 책무가 우선 된다고 보는 것이 타당할 것이다.

\section{KOICA 중장기 전략 수립}

\section{1. 중장기 전략 수립 배경: 대내외 환경 분석 결과}

\section{가. 국내 환경의 변화}

\section{1) 정부의 개발협력 추진의지 강화}

정부가 설정한 국정기조 및 국정목표에 대해 $\mathrm{KOICA}$ 의 기관차원의 중장기 경영목표를 연계하여 강화할 필요가 있다. 정부는 국정과제 및 국정 기조를 통해 ODA 규모를 확대하고 개발협력 산업의 활성화를 추진하고자 하는 강한 의지를 표명하였다. ${ }^{4}$ 아울러 ODA 시행부처간 협업 및 소통을 강화하

4) (ODA사업 관련 국정과제) ODA 규모 지속 확대, ODA 통합 추진 체계 공고화, 개발협력 글로벌 인재양성, 개도국들 에게 실질적인 도움이 되는 모범적 - 통합적 개발협력 추진, 글로벌 청년 프로젝트 확대 등을 통해 국제사회에 대한 우리의 인적 기여 증대.

(non-ODA 과제) 중소, 중견 기업의 수출 경쟁력 강화, 청년 친화적 일자리 확충 기반 조성, 문화유산 보존 활용 및 한국문화 진흥, 온실가스 감축 등 기후변화 대응 등. 
고 상생형 $\mathrm{ODA}$ 를 추진함으로써 수원국의 개발목표를 달성하는 동시에 한국 인력 및 기업의 해외진출 지원을 동시 추진할 것을 강조하고 있다.

또한 제1차 분야별 국제개발협력기본계획(2011-2015)이 올해 종료되고, 2016년부터 시작되는 제 2차 분야별 국제개발협력기본계획(2016-2020)에서는 이러한 정부의 ODA정책 방향을 반영하여 “SDGs 이행목표달성 기여”를 비전으로 제시하고, $\boldsymbol{\Delta}$ 통합적인 ODA, 새내실있는 ODA, $\boldsymbol{\Delta}$ 함께하는 $\mathrm{ODA}$ 를 기본방향으로 설정하였다. 3 대 기본방향 각각에 대하여 세부 추진과제를 아래와 같이 설정하 였다. ${ }^{5)}$

$\Delta$ 통합적인 ODA: 유 - 무상 통합 전략 강화, 무상 통합 전략 강화, 2 기 국가협력전략 $(\mathrm{CPS})$ 수립, 다자원조의 통합적 추진

\ 내실있는 $\mathrm{ODA}: \mathrm{ODA}$ 컨텐츠 재정비, 종료 $\mathrm{ODA}$ 사업 사후관리 강화, $\mathrm{ODA}$ 평가 - 환류 강화, 사업투명성 제고, 인도적 지원 확대

$\Delta$ 함께하는 ODA: 범국민 이해와 참여 증진, 민간파트너십 다원화 및 포용적 비즈니스 모델 확산, 삼각협력 활성화, 다양한 민간 재원 활용 확대, 글로벌 파트너십 강화

\section{2) ODA 집행주체의 지속적인 다원화}

오늘날 다수의 $\mathrm{ODA}$ 시행기관들은 기존에 $\mathrm{KOICA}$ 를 통해 $\mathrm{ODA}$ 사업을 실행하는 관행에서 벗어나 스스로 자체 $\mathrm{ODA}$ 사업을 형성 및 기획하고 수행함으로써 $\mathrm{ODA}$ 집행주체의 다원화가 가속화되고 있 다. 이로 인해 2000년 이후 우리나라의 $\mathrm{OECD} / \mathrm{DAC}$ 가입 및 원조규모 증가에 따라 각 정부부처의 $\mathrm{ODA}$ 에 대한 관심과 참여의지가 증가하였으며, 원조분절화 및 중복현상 역시 심화되고 있다. 무상원 조 시행부처는 2011년 22개에서 지속적으로 증가하여 2015년에는 31개로 늘어났다. 2015년의 경우 31 개 기관이 859 개의 무상 원조 사업(금액 8,446억 원)을 추진하였다. 지자체를 포함한 시행기관의 숫자는 더욱 늘어나며, 지자체가 전체 ODA 예산에서 집행하는 비중도 2010 년도 $0.2 \%$ 에서 2014년도 에는 잠정 $0.68 \%$ 로 늘어나는 추세다. ${ }^{6}$ 또한 2010년 기준, 총 43개의 ODA시행기관이 ODA 집행에 참여하였으나, 총 $\mathrm{ODA}$ 예산 중 기관별 예산비율이 $1 \%$ 이상인 기관은 8 개 기관 ${ }^{7}$ 에 불과하며, 그 외 기관들은 극히 소규모의 ODA만을 집행하는 것으로 나타났다.

5) 제2차 국제개발협력 기본계획(2015.11.10, 제 22차 국제개발협력위원회 의결사항)

6) 제2차 국제개발협력 기본계획 p.47(2015.11.10, 제 22차 국제개발협력위원회 의결사항)

7) 8 개 기관에는 KOICA, 수출입은행, 기획재정부, 외교부, 한국은행, 교육부, 농림부, 보건복지부가 있다. (출처: 2010 년 국무총리실 전수조사 기준) 


\section{3) 공공기관의 역할변화를 통한 상생형ODA 강조}

과학기술의 발전, 난민, 불평등 이슈 등 다양한 개발협력 과제가 복잡한 양상으로 전개됨에 따라 개발협력 기관 단독으로서는 수원국의 다양한 개발수요에 대응하기 어려운 실정이 되었다. 특히 국제 적으로 강조되는 부산글로벌 파트너십 및 Post-2015 개발협력 논의 등을 통해 포괄적 파트너십을 통 한 개발협력 이슈 대응이 강조되어가는 동시에 국내적으로 각 분야별 전문 역량을 갖춘 개발협력 시 행기관의 수도 점증하고 있다. 이에 따라 $\mathrm{KOICA}$ 를 비롯한 공공기관들은 원조사업에 있어 기존의 독 점적 문제해결자 혹은 서비스 공급자에서 벗어나 조정 및 촉진자적 역할을 수행함으로써 상호협력을 통한 시너지를 창출하는 $\mathrm{ODA}$ 를 추구할 것을 요구받고 있다.

\section{나. 국제 환경의 변화}

\section{1) Post-2015 중심의 신규 개발과제 논의 활성화}

2015년 MDGs 달성시한이 종료됨에 따라, 지난 2015년 9월 UN개발총회에서는 「2030 지속가능 개발의제(2030 Agenda for Sustainable Development)가 공식 채택되었으며, 오는 2016년 3월에 $\mathrm{SDGS}$ 세부지표 역시 최종 확정될 예정이다. 내년 SDGs 최종지표까지 확정되고 나면 개발목표는 향 후 15 년간의 국제개발 패러다임의 기본 틀로서 역할을 할 것이다. 따라서 SDGs 우리 정부가 제2차 국제개발협력 기본계획에서 비전으로 수립한 “SDGs 이행 목표 달성 기여”를 성실히 이행하기 위한 구체적인 대응 전략의 수립이 필요하다. 또한 지난 9월 뉴욕에서 개최된 유엔 개발정상회의에서 우리 정상이 공약한 “소녀들의 보다 나은 삶” 구상과 “지속가능한개발을 위한 농촌종합개발사업” 등의 주요 이니셔티브들의 구체 이행 전략이 필요하다.

\section{2) $\mathrm{ODA}$ 정의 변화와 개발재원 다각화}

$\mathrm{ODA}$ 정의변화와 정부주도의 $\mathrm{ODA}$ 감소, 다양한 개발재원의 확대 등의 변화에 맞추어 민간재원과 $\mathrm{ODA}$ 간 연계, $\mathrm{ODA}$ 와 기타재원과의 역할 및 기능 정립, 새로운 금융방식을 활용한 ODA 추진방안, 민 관파트너십 확대에 대한 조직적 대응이 필요하다. 이에 $\mathrm{KOICA}$ 는 선진 개발원조기관 및 선진 공여국 들을 중심으로 다양한 개발재원을 $\mathrm{ODA}$ 와 연계하는 방식으로 사업을 다각화하는 중이다. 또한 개발재 원의 외연 확대 및 TOSSD로의 ODA개념 변화는 개도국에 관련되는 재원과 이해관계자의 증대를 의 미한다는 점에서, $\mathrm{ODA}$ 가 개도국으로 유입되는 다양한 재원과 이해관계자의 촉진, 통합, 조정, 연계 및 방향성 제공 등 $\mathrm{KOICA}$ 의 새로운 역할이 필요하다. 


\section{3) 개발협력 이슈의 영역 확대}

최근 개발의 개념은 단순한 사회, 경제개발을 넘어서 안보, 인권, 취약국, 지속가능한 성장, 기후변 화 대응, 불평등 문제 등으로 개념 확대의 필요성이 증대되고 있다. 이에 따라 다양한 글로벌 과제의 해 결을 위한 새로운 글로벌 파트너십 구축의 필요성 역시 증대되고 있다. 특히 오늘날 ODA 범위에 있어 평화, 사법, 안보 관련 활동을 보다 포괄적으로 인정하려는 움직임이 있으며, TOSSD의 개념에 글로벌 공공재에 대한 지원, 특히 신재생 에너지에 대한 지원까지도 포함하여 산정하겠다는 논의가 커지고 있 다. 아울러 국제적 공조강화와 $\mathrm{UN}$ 을 비롯한 국제시스템의 일관되고 효과적인 대응이 필요하며, 정부 뿐만 아니라 시민사회, 민간부문, 학계 등 다양한 이해관계자들의 참여의 중요성 역시 커지고 있다.

\section{4) 혁신기술과 개발사업의 연계를 통한 효과성 제고 필요성 증대}

민간부문이 가진 혁신적인 기술과 창의적 아이디어를 개발협력에 접목시킬 필요성이 증대하고 있 다. 특히 수원국 요청에 기반한 사업발굴 방식으로는 혁신기술, 창의적 아이디어를 접목한 사업형성 에 한계가 노정된다는 점에서, $\mathrm{KOICA}$ 는 민간의 창조적 기술 및 아이디어를 개발협력에 반영한 혁신 적 사업을 기획 및 형성할 필요가 있다. 가령, 교육, 보건, 금융분야의 ICT를 활용하거나, 빅데이터와 ICT를 활용한 거버넌스 개선, 농업생산력 제고, 새로운 산업과 창업 기회의 창출, AIDS/HIV치료제 및 말라리아 백신 등 신약 개발 등 그 범위는 매우 광범위하다.

이러한 국내외적 개발 환경 변화를 바탕으로 KOICA를 비롯한 전세계 공여기관들은 Post-2015 에 기여가능한 $\mathrm{ODA}$ 패러다임과 전략을 마련할 필요성을 갖게 되었다. 이에 $\mathrm{KOICA}$ 는 원조기관으로 서 국내외적 경쟁력 향상을 위해 $\mathrm{KOICA}$ 의 중장기적 발전상(identity)을 명확히 드러내고, 기관의 발 전방향과제를 공유할 수 있는 소통기반을 마련하기 위해 지난 2014년 5월부터 KOICA 중장기전략 수 립계획을 확정하여 전략 수립에 착수하였다. 그 후 지난 1년여 기간 동안 KOICA가 단내 간부 및 본부 부서간의 협의를 통해 중장기전략 초안을 마련하였으며, 이에 대한 KOICA 해외사무소 및 외부전문 가, 기타 이해관계자와의 의견을 수렴하여 내용을 보완하는 작업을 진행하였다. 이를 통해 올해 2015 년 3월 $\mathrm{KOICA}$ 중장기 전략이 최종 수립되었다.

\section{KOICA 중장기 전략 주요 내용}

$\mathrm{KOICA}$ 는 이러한 다양한 개발문제를 해결하기 위해 필수적으로 요구받는 포괄적 파트너십을 적절 히 활용하기 위한 개방형 플랫폼을 구축하는 동시에 다양한 재원과 기술을 활용한 혁신적 가치창조의 시스템을 마련하고자 KOICA는 '지구촌 행복시대를 열어가는 개발협력 플랫폼'을 기관 비전으로 하는 $\mathrm{KOICA}$ 중장기전략을 수립하였다. 이는 Post-2015 개발체제를 중심으로 한 국제적 합의 및 우리나 라 정부차원의 이행 방향 모두를 반영함으로써 원조실행기관으로서 KOICA가 참여파트너들과의 협력 
을 통해 지구촌 행복시대를 구현할 수 있도록 성공적인 개발협력 플랫폼으로서 역할하는 것을 목표로 하고 있다.

$\mathrm{KOICA}$ 의 중장기 전략은 '지구촌 행복시대를 열어가는 개발협력 플랫폼'으로서의 역할 강화라는 비전 아래, 〈표 2 >와 같이 크게 5 개의 핵심가치를 지향하고, 이를 달성하기 위한 4 가지의 전략 목표 및 이에 대한 세부 전략과제를 수립하였다.

〈표 2〉 KOICA 중장기전략 비전체계
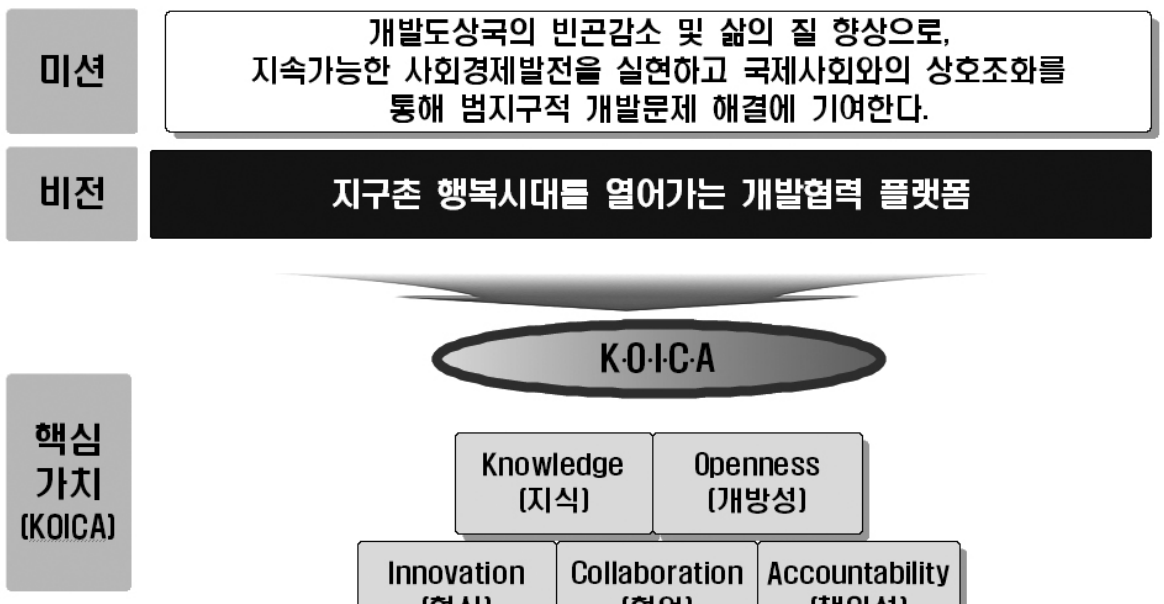
통해 범지구적 개발문제 해결에 기여한다.

\section{지구촌 행복시대틀 열어가는 개발협력 플랫폼}

\section{K.O.I.C.A}

\begin{tabular}{|c|c|c|c|}
\hline $\begin{array}{r}\text { Knov } \\
\text { IX }\end{array}$ & $\begin{array}{l}\text { edge } \\
\text { 식] }\end{array}$ & $\begin{array}{l}\text { Open } \\
\text { 개븐 }\end{array}$ & $\begin{array}{l}\text { ness } \\
\text { 항성] }\end{array}$ \\
\hline $\begin{array}{l}\text { Innovation } \\
\text { [혁신] }\end{array}$ & Collal & $\begin{array}{l}\text { ation } \\
\text { l] }\end{array}$ & Acco \\
\hline
\end{tabular}
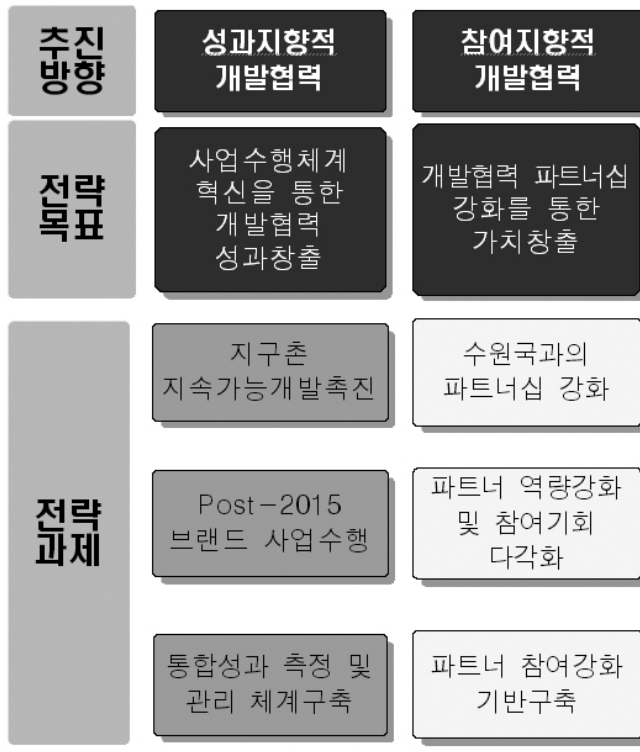

파트너 참여강화 기반구축
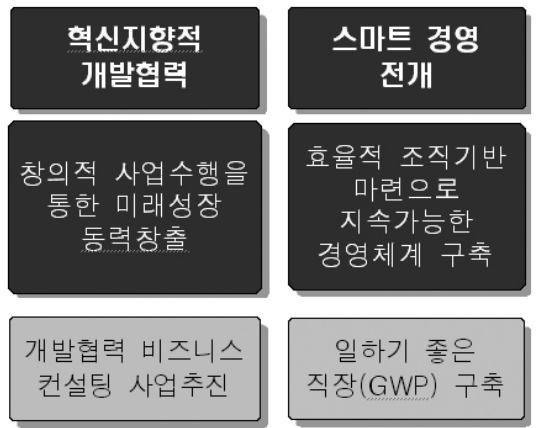

일하기 좋은 직장 $(\mathrm{GWP})$ 구축
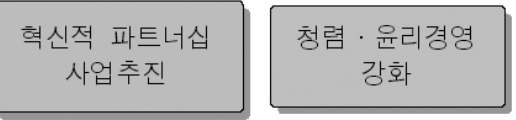

혁신적 가치창조 시스템 구축 


\section{가. 비전}

우선 $\mathrm{KOICA}$ 의 중장기 전략의 비전은 정부의 국정목표 달성을 도모하는 동시에 국내외 개발협력 주체들과 $\mathrm{KOICA}$ 와의 상호 협력을 촉진시키기 위한 장(場)으로서 개발협력 플랫폼 구축을 추구한다. 박근혜 정부는 국정목표에서 행복한 통일시대 기반구축을 위해 국제사회의 신뢰받는 모범국가로서 '지구촌 행복시대'에 기여하는 국가를 지향하고 있으며, 신뢰받는 정부를 구현하기 위해서는 개방 및 공유, 협력을 통한 정부 3.0 을 달성하고 깨끗하고 유능한 정부가 될 것을 주문하고 있다. 이러한 우리 정부의 목표를 달성하는데 기여하기 위해 $\mathrm{KOICA}$ 는 수원국, 선진공여국, 국내 ODA시행기관 등 다 양한 협력파트너들과의 협업을 통해 「2030 지속가능개발의제를 비롯한 폭넓은 국제개발현안(global challenges)을 함께 해결함으로써 지구촌 행복시대를 구현하는데 기여하고자 한다.

$\mathrm{KOICA}$ 는 기존에 $\mathrm{KOICA}$ 주도로 각각 협력 파트너들의 필요를 지속적으로 충족시키는 '독점적 문 제해결자' 지위에서 벗어나 다양한 개발주체들간의 네트워크를 형성하여 공급자와 수요자간의 필요를 스스로 충족함으로써 자가 혁신이 가능하도록 하는 네트워크 '개발협력 플랫폼' 형성을 추구하고 있 다. $\mathrm{KOICA}$ 는 국내외 개발협력들과 $\mathrm{KOICA}$ 가 공통적으로 활용할 수 있는 장을 구축함으로써 상호협 력을 통해 개발협력의 가치 향상을 도모하고자 한다(〈그림 2〉 참조).

\section{〈그림 2〉 개발협력플랫폼 개념}

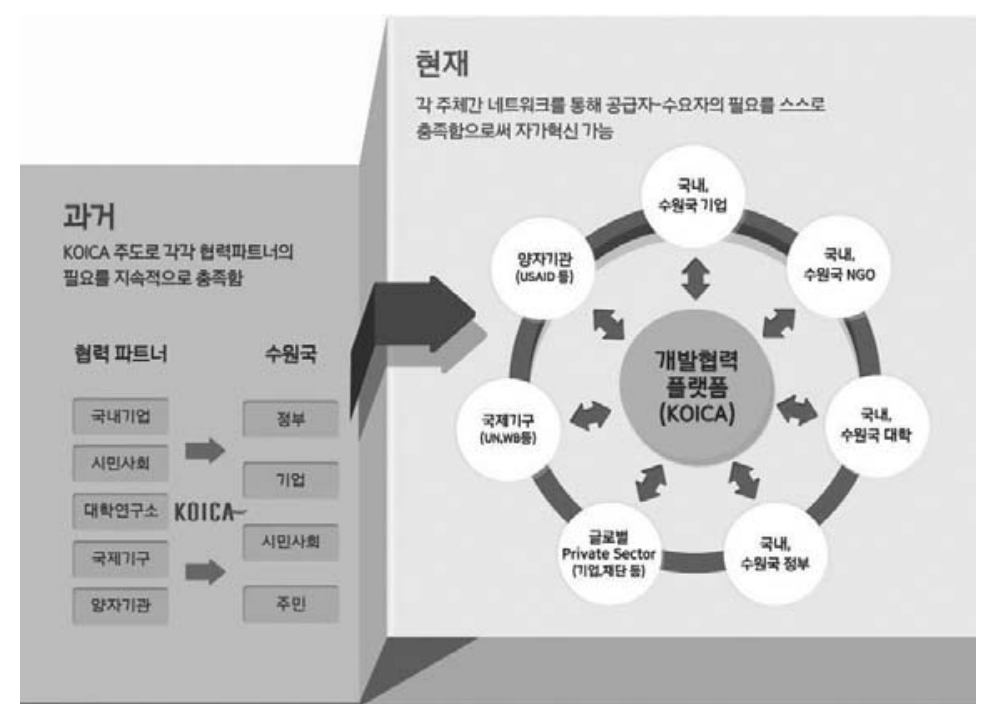

출처: KOICA (2015a) 
개발협력플랫폼은 국내 개발협력 생태계 번성을 위하여 아래 〈그림 3 〉과 같이, 크게 '사업공유', '지식공유', '자원공유'의 3대 플랫폼 축으로 구성되어 있다.

\section{〈그림 3〉 개발협력플랫폼의 주요역할}

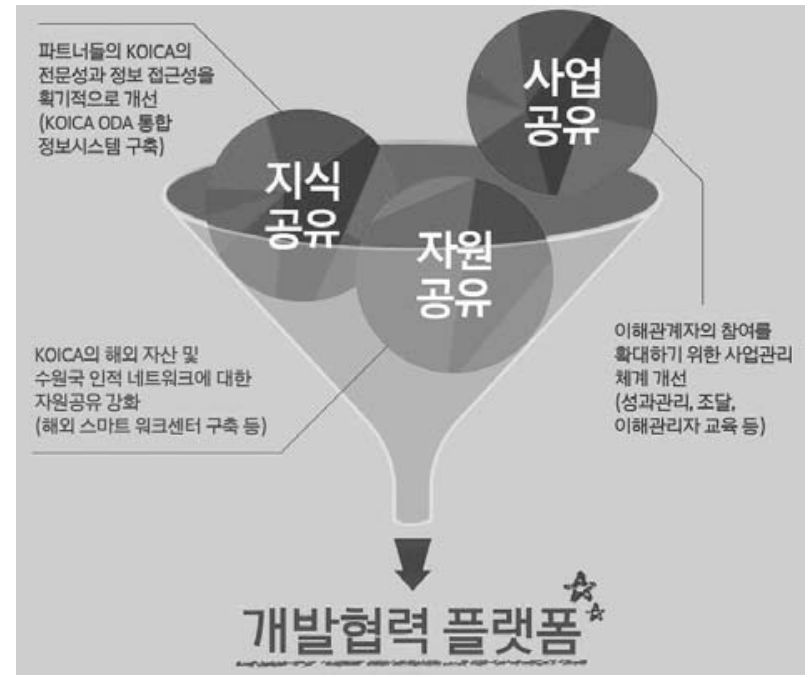

출처: KOICA (2015a)

우선 사업공유 플랫폼은 국내의 개발협력파트너들에게 KOICA의 개발협력사업추진 know-how 를 기반으로 사업관련 정보시스템을 개방하는 것이며, 대표적으로 개발협력 사업추진 시스템, 조달 시스템, 교육 및 역량 개발시스템, 성과관리 시스템의 4가지 정보 시스템을 개방하고자 한다. 이를 위 하여 각 시스템을 사용자 친화적이고 효율적으로 개선하는 것을 과제로 추진 중이다.

지식공유 플랫폼이란 개발협력과 관련된 모든 이해관계자들이 원하는 정보를 원하는 시간과 방법 으로 제공할 수 있는 시스템을 구축하는 것이며, 이를 위하여 2014년부터 KOICA 통합정보시스템 구 축을 과제로 추진하고 있다.

마지막으로 자원공유 플랫폼은 $\mathrm{KOICA}$ 의 해외 인프라 및 수원국의 인적 네트워크에 대하여 개 발협력 이해관계자들과 자원공유를 위하여 KOICA 사무소를 개발협력 공유서비스센터화(Shared Service Center, KOICA SSC)하고 수원국 핵심인력 네트워크 자원에 대한 공유 서비스(Key Man Network Management 플랫폼)를 제공하고자 하는 것이다. 
이러한 KOICA 개발협력 3대 플랫폼 요소 구축의 목표는 국내 개발협력 생태계 번성을 위한 장 (場)을 마련하고 각 플랫폼을 이용하고자 하는 이해관계자들과 함께 한국의 개발협력의 질적 성장 을 도모하고자 하며, 나아가 한국의 개발협력의 위상을 제고하여 공여국으로서의 국격을 높이는 것 이다.

\section{나. 핵심가치}

$\mathrm{KOICA}$ 는 기관 및 임직원 모두가 $\mathrm{KOICA}$ 의 미션, 비전, 전략 달성을 위해 필수적으로 갖추어야할 핵심 역량 및 가치로서 지식, 개방성, 혁신, 협업, 책임성 등 5 가지로 설정하고 조직 및 임직원 모두가 본 핵심역량 및 가치를 지니고자 적극적으로 노력하겠다는 의지를 담아 본 핵심가치의 영문명 앞 글 자를 따서 $\mathrm{KOICA}$ 로 명명하고 있다. 5 가지 핵심가치에 대한 각각의 목표는 다음 〈표 3 과 같다.

\section{〈표 3〉 KOICA 중장기 전략의 5 대 핵심가치}

\begin{tabular}{c|c|c}
\hline 구분 & 핵심가치 & 주요 목표 \\
\hline 1. K & $\begin{array}{c}\text { Knowledge } \\
\text { (지식) }\end{array}$ & 지식 및 전문성을 바탕으로 성과지향의 플랫폼 견인 \\
\hline 2. O & $\begin{array}{c}\text { Openness } \\
\text { (개방성) }\end{array}$ & 국내외 파트너를 대상으로 한 투명한 원조를 통해 신뢰의 리더십 발휘 \\
\hline 3. I & $\begin{array}{c}\text { Innovation } \\
\text { (혁신) }\end{array}$ & 혁신지향적 개발협력으로 지속가능한 개발 선도 \\
\hline 4. C & $\begin{array}{c}\text { Collaboration } \\
\text { (협업) }\end{array}$ & 소통 - 참여 · 협력에 기반한 상생의 파트너십 지향 \\
\hline 5. A & $\begin{array}{c}\text { Accountability } \\
\text { (책임성) }\end{array}$ & KOICA의 의사결정, 행동, 결과에 대한 책임성 지향 \\
\hline
\end{tabular}

출처: KOICA (2015a)

\section{다. 추진전략}

$\mathrm{KOICA}$ 는 정부의 국정기조 및 국정과제, 국제 환경 변화 등을 반영하여 총 4 개의 전략목표 및 12 개의 전략과제를 설정하였다. $\mathrm{KOICA}$ 중장기전략의 추진방향은 크게 $\mathrm{KOICA}$ 각 분야별 $\mathrm{KOICA}$ 차 원의 SDGs 주류화 작업을 중심으로 한 '성과지향적 개발협력'과 이러한 전략의 효과적인 이행을 위 한 주요 이행메커니즘으로서 SDGs의 이행수단 및 글로벌파트너십 등을 포함하는 '참여지향적 개발협 
력', ‘혁신지향적 개발협력', ‘스마트경영 전개’ 로 구성되어 있다.

\section{1) 성과지향적 개발협력}

$\mathrm{KOICA}$ 는 국제개발의제를 중심으로 한 성과체계를 확립함으로써 기관의 미래성장 기반을 구축해 야한다는 필요성에 절감하고 사업수행체계 자체의 혁신을 통하여 개발협력의 성과를 창출하고자 한 다. 이에 대한 세부 전략과제는 Post-2015 브랜드사업 수행, 통합성과 측정 및 관리체계 구축, 지구 촌 지속가능 개발 촉진 등 총 3 가지로 구성되어 있다.

- Post-2015 브랜드 사업 수행: Post-2015 브랜드사업* 중심으로 사업구조 개편, 업무효율성 증대 및 Post-2015 브랜드 중심의 성과관리 기반을 구축한다. KOICA 사업의 목표를 국제개발 목표와 일치(align)시키고자 기존 사업을 Post-2015 목표 등을 기준으로 통합하고, 원조예산의 효과적인 활용을 위하여 단위 사업규모를 확대, 브랜드사업 모듈정립, 결과중심의 사업기획 및 심사 절차를 대폭 강화하고자 한다. 현재 KOICA 5 대 중점분야?3개 범분야에 대한 분야별 중기 전략에 Post-2015 브랜드화를 추진 중이며, 2016년 6월까지 전 분야에 대한 전략수립 완료 예 정이다.

* 5대 중점분야: 교육, 보건, 공공행정, 농림수산, 산업에너지

** 3 대 범분야: 젠더, 기후변화, 과학기술혁신

* (브랜드 사업 정의) (1) 국제개발의제(post-2015 등)에 직접적으로 기여하며, (2) 수혜자 중심의 정량적 성과관 리 체계를 갖추고, (3) 개발목표별로 정렬되어 다양한 사업모듈과 형태(modality)로 구성된 KOICA의 대표사업 (flagship program)으로 추진

- 통합성과 측정 및 관리체계 구축: 기관의 성과목표를 객관적 - 정량적으로 통합 관리할 수 있는 체계를 구축하되, 국제사회의 개발목표와 기관-사업-직원의 성과목표간의 연계를 강화하는 성 과 관리 체계를 구축한다. 이를 통하여 SDGs에 대한 기여도를 대내외에 이해하기 쉽고 투명하 게 공개하여 기관의 성격에 부합하는 성과제시로 예산의 가치(value for money)를 극대화한다.

- 지구촌 지속가능 개발 촉진: Post-2015 브랜드 사업 이외에 다양한 국내외 개발관련 의제를 실천함으로써 개발협력 성과 제고에 기여한다. KOICA 중장기 전략의 수립이 유엔의 2030 지 속가능개발의제 공식 채택보다 앞선 시점에서, $\mathrm{KOICA}$ 의 Post-2015 브랜드사업이 도입되기 전의 과도기적 체제에서 $\mathrm{KOICA}$ 가 국제사회의 다양한 개발협력의제를 실천하는 내용을 담고 있다. 


\section{2) 참여지향적 개발협력}

아울러 $\mathrm{KOICA}$ 는 우량 파트너 육성 및 인재 양성, 참여기회 다각화를 통해 수원국, 사업시행기관, 개발협력 인재 등 다양한 파트너들의 전문성을 결집하는 방식의 개발협력 파트너십을 강화함으로써 사업성과 확대라는 가치를 창출하고자 한다. 이에 대한 주요 전략과제는 다음과 같다.

- 수원국과의 파트너십 강화: 수원국과의 협력강화 및 참여적 거버넌스 구축을 통해 수원국의 자 립도 및 개발협력사업의 지속가능성을 제고하고 수원국의 우수성과자원의 외연을 확대하고자 한다.

- KOICA 파트너 참여강화 체계 구축: 체계적인 이해관계자 관리기반을 구축하고, 우량파트너 의 참여 참대를 위한 제도 인프라 확립을 통해 우량 파트너 및 인재의 전문성 축적 기반을 구 축해야 한다.

- 파트너 역량 강화 및 참여 프로그램 개선: 우량 파트너 육성 추진, 사업참여 기회 다각화 추진, 개발협력 산업 인재 육성을 통해 개발협력사업 품질 및 성과를 제고하고자 한다.

\section{3) 혁신지향적 개발협력}

$\mathrm{KOICA}$ 는 혁신적 아이디어 및 기술등을 개발협력사업에 접목시키고, 개발협력플랫폼으로서 신규 사업 및 전문영역을 발굴하여 신규가치를 창출시키고자 하는 혁신지향적 개발협력을 추구하고 있다. 이에 대한 주요 전략과제는 다음과 같다.

- 혁신적 가치창조 시스템 구축: 다양한 IT기반 및 역량을 구축함으로써 혁신활동을 촉진하여 개 발협력플랫폼으로서의 역할 강화하고자 한다.

- 혁신적 파트너십 사업 추진: $\triangle$ 외부의 새로운 아이디어 및 신기술, 적정기술을 협력사업에 접 목, $\triangle$ 개발협력사업의 가치 및 성과를 제고해야 한다.

- 개발협력 비즈니스 컨설팅 사업 추진: $\triangle$ 컨설팅형 업무의 공식화 및 기관성과 반영, $\triangle$ 개발협 력 비즈니스 관련 컨설팅 사업기반을 구축하는 등 풀랫폼 기관으로서 신성장 사업 영역을 발굴 하고, 새로운 가치 창출 가속화하고자 한다.

\section{4) 스마트경영 전개}

또한 $\mathrm{KOICA}$ 는 조직개선, 업무프로세스 개선 등을 통해 경영체질을 강화하고, 업무의 효율성을 제 고함으로써 다양한 전략과제를 추진하기 위한 인프라 구축을 목표로 스마튼 경영을 전개하고자 한다. 이에 대한 주요 전략과제는 다음과 같다. 
- (전략 경영 강화) 조직, 인사, 재무 및 업무 프로세스 개선을 통해 전략과제 실행기반 구축하고 자 한다.

- (청렴 · 윤리경영 강화) 청렴업무에 대한 제도개선 및 청렴한 조직문화 형성, 사회적 신뢰기반 구축, 규제완화 등을 통해 경영의 지속가능성 제고해야 한다.

- (일하기 좋은 직장 실현) 내부 소통 강화 및 복지 향상 등을 통해 업무환경 및 문화를 개선함으 로써 업무생산성을 향상하고자 한다.

\section{KOICA 중장기 전략에서의 SDGs 주류화}

\section{KOICA 중장기전략 3대 핵심과제 및 5 대 브랜드 프로그램}

\section{가. KOICA 중장기 전략 3대 핵심과제}

$\mathrm{KOICA}$ 는 현재 $\mathrm{KOICA}$ 중장기전략 내에서 SDGs 기여를 위한 $\mathrm{KOICA}$ 의 주요 추진전략을 설정하 였다. KOICA의 중장기전략 3대 핵심과제로는 (1) SDGs 이행전략 수립, (2) Post-2015 브랜드 사업 추진, (3) SDGS와 연계한 통합성과관리 체계구축 등으로, 이는 $\mathrm{KOICA}$ 중장기전략상 '성과지향적 개 발협력' 내 각 전략과제에 해당하는 부분이다. 특히, 이 중에서도 Post-2015 브랜드사업화는 앞에서 밝힌 바와 같이, 현재 $\mathrm{KOICA}$ 가 5 대 중점분야 및 3 개 범분야에 대한 분야별 중기전략 수립과 함께 추 진하고 있으며, 이는 2016년 6월 최종완료될 예정이다.

\section{나. KOICA 5대 브랜드 프로그램}

아울러 앞선 중장기전략 3대 핵심과제와 함께 SDGs 달성을 보다 적극적으로 달성하는데 기여하 기 위해, KOICA는 각 테마별 브랜드 프로그램을 발족하였다. 이에 따라 $\mathrm{KOICA}$ 의 중장기전략 3 대 핵심과제를 바탕으로 한 5 대 브랜드 프로그램의 전략을 수립하였으며, 그 세부내용은 다음 〈Box 3〉 과 같다. 


\section{〈Box 3〉SDGs KOICA 5대 브랜드 프로그램}

(1) 새마을운동을 통한 지속가능하고 포용적인 개발(Saemaul Undong for Sustainable and Inclusive Development)

(2) 소녀들의 보다 나은 삶(Better Life for Girls)

(3) 모두를 위한 안전한 삶(Safe Life for All)

(4) 보다 나은 삶을 위한 과학기술혁신(STI(Science, Technology \& Innovation) for Better Life)

(5) 안전한 물과 청정에너지를 통한 기후변화 대응(Safe Water \& Clean Energy for Climate Change Response)

출처: KOICA (2015b)

$\mathrm{SDGs} \mathrm{KOICA}$ 5대 브랜드 프로그램 중 첫 번째는 '새마을운동을 통한 지속가능하고 포용적인 개발 (Saemaul Undong for Sustainable and Inclusive Development)'이다. 본 프로그램은 단기간 내 절대적 빈곤문제를 해결하고 농촌발전이라는 가시적 성과를 거둔 우리나라의 대표적인 개발 모델로서 개도국 및 국제사회는 새마을운동 모델을 빈곤퇴치 및 농촌개발의 좋은 모델로서 평가받고 있다. 본 프로그램의 중점지원 분야는 크게 4 가지로, 그 세부사항은 다음 〈Box 4〉와 같다.

\section{〈Box 4〉'새마을운동을 통한 지속가능하고 포용적인 개발' 중점 지원분야}

(1) 기업과의 포용적 파트너십 통한 새마을운동의 확산

- 우리 기업과의 전략적인 새마을 파트너십을 통해 개도국의 농촌 경제 활성화, 고용창출 및 소득증대에 기여(민간기업의 비즈니스적 수요)를 연계한 사회투자형 사업으로 협력 모델을 구축)

(2) 농업 가치사슬 강화를 통한 개도국 주민의 소득 증대

- 농업의 가치치슬 강화를 통해 개도국 마을을 하나의 Business Unit화하는 전략으로 농작물 생산량 증대 를 위한 농기계 교육· 훈련, 인프라 구축뿐만 아니라 생산물의 수확 후 관리, 가공 및 유통, 마케팅 강화 를 목표

(3) 적정기술 활용을 통한 개도국 농촌에 창조경제 구현

- 개도국 현지에 맞는 적정기술의 활용뿐만 아니라, 급변하는 외부세계에 적응 가능한 신기술과 재생에너 지를 사업요소로 적극 활용

(4) 국제사회 주요 개발기관과 협업을 통한 새마을운동 현대화

- 스마트 새마을운동의 개발협력모델을 확산하기 위해 국제기구 및 국제NGO와 협업하고, Millenium Promise, WFP, UNDP, OECD 등 스마트 새마을운동에 관심을 가지고 있는 공여기관들과 공동사업 추 진, 공동 연구 및 사업평가 진행

출처: KOICA (2015b) 
두 번째 브랜드 프로그램은 '소녀들의 보다 나은 삶(Better Life for Girls)'이다. 본 프로그램은 개 발도상국 여성청소년에 대한 양질의 교육 제공, 건강한 보건 환경 조성, 미래역량 강화를 통해 여성 리더 양성, 양성평등사회 실현, 사회경제적 발전에 효과적으로 기여를 목표로 하며, 초등학교 고학년 을 포함한 10대 여성청소년(10-20세)을 수혜대상으로 설정하고 있다. 중점지원분야로는 크게 교육 (Girls' Right to Education), 보건(Girls' Right to Health), 직업(Girls' Right to Profession) 등이 있으며, 그 세부 내용은 다음과 같다.

\section{〈Box 5〉'소녀들의 보다 나은 삶' 브랜드 프로그램 중점 지원 분야}

(1) 교육(Girls' Right to Education)

- 읽기, 쓰기, 과학, 수학 등 학습성과 제고

- 취약계층, 재난 및 분쟁 지역 여성청소년 교육기회 확대

(2) 보건(Girls' Right to Health)

- 학교 내 청소년 보건교육 강화 및 학교위생환경 구축

- 지역사회 및 의료시설 기반 여성청소년 친화적 성생식보건 서비스강 화

(3) 직업(Girls' Right to Profession)

- ICT, 회계 등 공통역량 교육 및 기술 훈련으로 직업역량 강화

- 지역사회 여성인재 양성으로 사회적, 경제적 자립도 제고

출처: KOICA (2015b)

세 번째 브랜드 프로그램은 '모두를 위한 안전한 삶(Safe Life for All)'로서, 본 프로그램은 에볼라, $\mathrm{SARS}$ 등 신종 감염병을 신속히 발견, 보고하고 국제 보건안보(GHSA) 분야 지원을 통해 질병전파를 조기에 차단, 개도국발전 및 국제안보에 기여할 것을 목표로 한다. '모두를 위한 안전한 삶 브랜드 프 로그램의 중점 지원분야는 다음과 같다.

\section{〈Box 6〉'모두를 위한 안전한 삶' 브랜드 프로그램 중점 지원 분야}

(1) 예방 영역: GHSA 하부 계획 중 예방접종(Immunization) 분야 지원

- 감염병 예방백신 생산을 위한 국제사회의 노력에 기여

(2) 탐지 영역: 하부 계획 중 $\triangle$ 국가실험실체계 강화 및 $\triangle$ 보건안보 인력역량강화 지원

- 개도국 보건 거버넌스의 자체 역량 강화 및 효과지속성 제고 기대

출처: KOICA (2015b)

다음으로, 네 번째 SDGs KOICA 브랜드 프로그램은 '보다 나은 삶을 위한 과학기술혁신 (STI(Science, Technology \& Innovation) for Better Life)'이다. 이는 과학 · 기술 · 혁신을 통해 사 
회경제 서비스분야에서 접근성을 높여 개도국 주민들의 삶의 질을 개선하고, 포용적 성장을 실현하 며, 지속가능성장을 위한 동력을 확보하여 SDGs 달성에 기여할 것을 목표로 한다. 과학기술혁신 관 련 본 브랜드 프로그램의 중점 지원 분야는 다음과 같다.

\section{〈Box 7〉 ‘보다 나은 삶을 위한 과학기술혁신’ 브랜드 프로그램 중점 지원 분야}

(1) (정책컨설팅) 개도국의 과학기술혁신 정책 · 제도 수립 및 집행 역량 강화

- 산업, 대학, 연구원, 클러스터 등 R\&D 혁신역량 강화 지원

(2) (과학 - 기술 교육) 과학교육, 기술교육, 공학교육 분야 고급 과학 기술인력 양성

- 기초 과학기술 교육 강화 및 산업분야 기술인력(직훈원 및 폴리텍) 양성 벤처기업가형 및 사회문제 해결형 과학기술 인력 교육과정 개설

(3) (연구개발 지원) 사회개발 - 산업 수요에 맞춘 R\&D 기관의 활동 및 역량 강화

- $\boldsymbol{\Delta}$ 국내-개도국 연구기관간 양자협력, $\boldsymbol{\Delta}$ 국내-개도국-선진공여국 연구기관 간 삼자협력을 통한 공동연 구 및 기술혁신 활동 지원

(4) (기업 등 민간영역) 기업, 민간단체 등 민간의 기술혁신 · 사업화 역량 강화

- 「창의혁신 개발센터」 건립 · 지원을 통한 창업 서비스 제공

- 개도국 주민 대상 비즈니스 기회 창출 프로그램 운영

- 기술기반 기업과의 민관협력 프로젝트 강화

(5) 범분야(cross-cutting)에 걸쳐 과학기술 기반 솔루션 적용 확대

- 보건, 교육, 농업, 공공행정, 환경 등 분야별 사업에 과학기술 적극 활용

출처: KOICA (2015b)

마지막으로 다섯 번째 브랜드 프로그램은 '안전한 물과 청정에너지를 통한 기후변화 대응(Safe Water \& Clean Energy for Climate Change Response)'이다. 본 브랜드 프로그램은 현재 내부 검 토 중에 있다. 본 프로그램은 개발도상국의 저탄소 사회로의 전환 및 생명유지와 경제활동의 근간이 되는 수자원의 지속가능성 확보, 기후변화에 따른 재해 경감, 미래역량 강화 활동을 통한 기후변화 취 약성 감소 및 지속가능한 성장에 기여할 것을 목표로 한다.

\section{〈Box 8〉 '안전한 물과 청정에너지를 통한 기후변화 대응' 브랜드 프로그램 중점 지원 분야}

(1) 수자원 분야의 통합적인 접근 및 지원

- 식량안보확보를 위한 농촌지역의 수자원시설 확충, 지역사회 발전을 고려한 농어촌개발 사업 및 새마을 운동 사업 지원

- 안전한 식수와 위생시설 접근을 위한 인프라 환경 구축, 보건위생인식 및 생활습관 개선 서비스 강화

- 도시화, 기후변화 등에 따른 가용 수자원의 지속가능성 확보 및 물관련 재해대응을 통한 회복력 증대

- 물 분야에 취약한 거버넌스 체계 구축, 물 안보 및 관리 역량 강화를 위한 프로그램 지원

(2) 청정에너지의 보급 및 에너지 효율 향상

- 태양광, 풍력, 소수력, 바이오 에너지, 페기물 연료화 등 시설 확충 및 제도 구축

- 에너지 저장장치(ESS), 고효율 조명(LED) 등 에너지 효율 개선 시설 확충 
따라서 $\mathrm{KOICA}$ 중장기전략 상의 SDGs 달성을 위한 노력은 크게 중장기전략 전체 차원에서의 전 략수립과 이행메커니즘 구성에 따라 아래와 같이 이루어진다고 할 수 있다. 즉, SDGs 기여를 위한 중 장기전략 3 대 핵심과제 및 5 대 브랜드 프로그램의 전략을 수립하고, 이에 대한 다양한 참여적, 혁신적 개발협력방식과 스마트 경영방식 등 다양한 이행메커니즘의 적절한 적용을 통하여 본 전략을 효과적 으로 이행함으로써 $\mathrm{KOICA}$ 의 사업운영 방향이 SDGS가 목표하는 개발방향에 부합하도록 운영하고자 한다(〈표 4〉참조).

〈표 4〉SDGs 달성을 위한 KOICA 중장기전략 구성

\section{제I장}

개

발

제II장

제III장

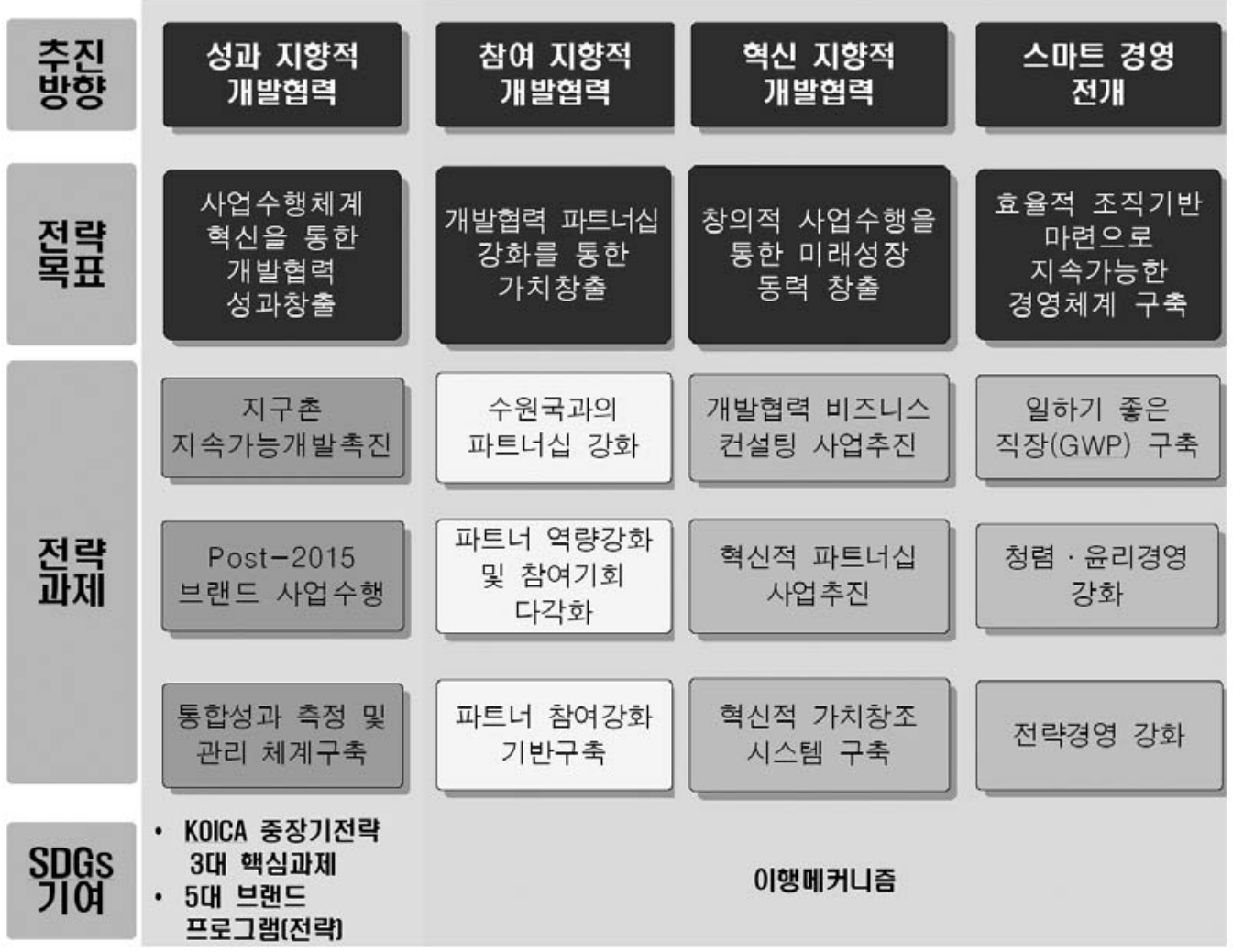

출처: KOICA (2015a) 재구성 


\section{2. 이행 용이성에 따른 SDGs target 분류}

기존 MDGs에 비해 새로운 SDGs 체제하에서는 국제사회가 달성해야할 목표의 수가 현저히 증가 하였다. 17 개의 목표와 169 개의 세부목표라는 엄청난 과제에 직면한 현재, KOICA는 SDGs의 세부목 표 중에서 최대한 많은 내용을 $\mathrm{KOICA}$ 전략 및 사업에 반영하고자 노력하고 있다. 이를 위한 시작점 으로, $\mathrm{KOICA}$ 는 SDGs를 바탕으로 (1) 공여국의 국내 이행부문 및 (2) 수원국에 대한 공여국의 ODA사 업, (3) 수원국, 공여국간의 글로벌 파트너십을 요하는 목표들을 분류함으로써 각 준위별로 이행가능 한 목표체계를 규명하는 작업을 시도하고 있다. 따라서 이번 장에서는 공여국의 ODA활동에 있어 실 제 어떤 세부목표(targets)들이 주로 관련되는지 살펴보고, 이를 바탕으로 해당 세부목표들을 다시 $\mathrm{ODA}$ 활동의 이행 용이성 정도에 따라 분류함으로써 우선적으로 이행가능한 세부목표들이 무엇인지를 살펴보고자 한다.

\section{가. 이행주체에 따른 SDGs target 분류(안)}

먼저 '선진국 국내', '선진국 ODA 개발협력', ‘글로벌 파트너십'으로 준위를 나누어 각 카테고리별로 이행가능한 SDGs 세부목표들을 분류하는 작업을 시도하였다(〈표 5 〉참조). 본 분류작업 자체에 자의 적인 해석이 개입되었다는 점은 사실이나, SDGs 목표체계를 바탕으로 한 이러한 분류작업이 국내 최 초로 시도되었다는 점에서 유의미하다고 할 수 있다.

〈표 5〉이행주체에 따른 SDGs target 분류체계(안)

\begin{tabular}{|c|c|c|c|}
\hline 목표 & 선진국 국내 & 선진국 개발협력 & 글로벌 파트너십 \\
\hline 목표 1. 빈곤 & $1.2 / 1.3$ & 1.1/1.2/1.3/1.4/1.5/1.a/1.b & 1.a/1.b \\
\hline 목표 2. 농업 & 2.b & 2.1/2.2/2.3/2.4/2.5 & 2.5/2.a/2.b/2.c \\
\hline 목표 3. 보건 & $3.4 / 3.5 / 3.6 / 3.9$ & $\begin{array}{l}\text { 3.1/3.2/3.3/3.4/3.7/3.8/ } \\
\text { 3.9/3.b/3.c/3.d }\end{array}$ & 3. $a$ \\
\hline 목표 4. 교육 & 4.7 & $\begin{array}{l}\text { 4.1/4.2/4.3/4.4/4.5/4.6/ } \\
\text { 4.7/4.a/4.b/4.c }\end{array}$ & \\
\hline 목표 5. 젠더 & 5.1/5.2/5.4/5.5/5.b/5.c & 5.1/5.2/5.3/5.4/5.5/5.6/5.a/5.b/5.c & \\
\hline 목표 6. 식수/위생 & $6.3 / 6.4 / 6.5 / 6.6$ & 6.1/6.2/6.4/6.6/6.b & 6.5/6.a \\
\hline 목표 7. 에너지 & 7.2/7.3/7.a & 7.1/7.2/7.3/7.b & 7.a \\
\hline 목표 8. 경제/고용 & $\begin{array}{l}\text { 8.1/8.4/8.5/8.6/8.8/8.9 } \\
/ 8 . b\end{array}$ & 8.1/8.2/8.3/8.7/8.10/8.a & \\
\hline
\end{tabular}




\begin{tabular}{|c|c|c|c|}
\hline 목표 9. 인프라 & 9.2/9.4/9.5/9.b & 9.1/9.3/9.a/9.c & \\
\hline 목표 10. 불평등 & $\begin{array}{l}\text { 10.1/10.2/10.3/10.4/10.5/ } \\
10.7 / 10 . c\end{array}$ & 10.b & 10.6/10.7/10.a \\
\hline 목표 11. 도시 & $\begin{array}{l}\text { 11.2/11.4/11.5/11.6/11.7/ } \\
\text { 11.a/11.b }\end{array}$ & 11.1/11.2/11.3/11.c & \\
\hline 목표 12. 생산/소비 & 목표 12 전체 & 12.1 & \\
\hline 목표 13. 기후변화 & 목표 13 전체 & 13.b & 13.a \\
\hline 목표 14. 해양환경 & 목표 14 전체 & 14.7/14.a & 14.c \\
\hline 목표 15. 육상환경 & 목표 15 전체 & & 15.3/15.a/15.c \\
\hline 목표 16. 거버넌스 & $\begin{array}{l}\text { 목표 } 16 \text { 전체 } \\
(16.4 / 16.5 / 16.9)\end{array}$ & & 16.8 \\
\hline 목표 17. 이행수단 & $\begin{array}{l}\text { 17.3/17.7(선진국-개도국 } \\
\text { 상호합의)/17.14/17.15 }\end{array}$ & 17.1/17.2/17.4/17.5/17.8/17.9/17.18 & $\begin{array}{l}17.6 / 17.8 / 17.9 / \\
17.10 / 17.11 / 17.12 / \\
17.13 / 17.15 / 17.16 / \\
17.17 / 17.19\end{array}$ \\
\hline
\end{tabular}

\section{〈Box 9〉이행주체에 따른 SDGs target 분류 기준}

- 선진국 국내: SDGs의 기본 정신이 ‘보편성’임을 감안해야 하나, 선진국 (한국)의 국내적 이행과제가 더 우선되거 나, 개발도상국의 이행역량이 현저히 낮아 이행하기 어려운 세부목표

- 선진국 개발협력: 개발도상국의 국내이행과제이면서 ODA 또는 기타 투자를 통해 선진국 개발협력 사업으로 이 어질 수 있는 세부목표

- 글로벌 파트너십: 개발협력 또는 환경보호를 위해 국제적인 파트너십을 강조하였거나, 국제조약의 준수 등의 내 용을 포함한 세부목표

출처: 저자작성

위의 〈표 5〉는 〈Box 9〉의 분류기준에 따라 이행주체별로 SDGs target을 나누어 제시하고 있다. $\mathrm{SDGs}$ 목표 분류를 보면, 빈곤, 농업 등을 비롯한 앞단의 목표들의 경우 MDGs를 계승 및 확대한 사 안들로서, 본 목표달성을 위한 이행방안이 이미 어느 정도 마련되어 있는 상황이다. 하지만, 육상환 경, 거버넌스 등 뒷단의 목표들의 경우, 기존 MDGs의 반성을 통해 새로이 등장한 목표들로서, 본 목 표 달성을 위해서는 이를 위한 새로운 이행수단들을 마련해야 한다. 
이러한 점을 보았을 때, 선진국의 경우, 국내적으로 $\mathrm{SDGs}$ 를 이행하고자 할 때 이전 보다 많은 이 행과제가 발생하게 되며, $\mathrm{ODA}$ 사업활동에서는 비교적 기존의 이행방안 및 경험을 바탕으로 운용가능 하다고 할 수 있다. 아울러 선진국 국내 및 선진국 ODA 사업 준위에서의 SDGs 이행을 위해 부족한 부분은 새로운 개발재원 및 글로벌 파트너십을 보다 활용함으로써 보완가능하다고 할 수 있다.

\section{나. ODA사업 이행 용이성에 따른 SDGs 목표 분류}

위에서의 이행주체별 SDGs target 분류에서 개발도상국의 주요 국내이행과제이자 KOICA가 $\mathrm{ODA}$ 및 기타 투자를 통해 실제로 사업화 할 수 있는 부분은 바로 '선진국 개발협력' 부문이다. 이러한 점에서 $\mathrm{KOICA}$ 가 $\mathrm{ODA}$ 사업을 이행하기에 용이한 세부목표들을 구분해보고자 한다. 본 분류작업 또 한 SDGs 세부목표의 전략화 과정에서 KOICA 뿐만 아니라 기타 ODA 시행기관들 역시도 동일하게 고민하는 부분일 것이라는 점을 고려하여 저자가 자체적으로 구분하여 제시하고자 한다. 아래〈표 6〉 에서는 〈box 10〉에서의 기준을 바탕으로 선진국 개발협력 사업 부문을 SDGs 이행과업별로 분류하여 해당 target을 정리하였다.

〈표 6〉 선진국 개발협력 해당 SDGs 이행과업별 target 분류(안) ${ }^{8)}$

\begin{tabular}{|c|c|c|c|}
\hline 목표 & 이행과업 & 중장기목표 과업 & 도전과업 \\
\hline 목표 1. 빈곤 & $1.1 / 1.2 / 1.3 / 1.4$ & 1.5/1.a/1.b & \\
\hline 목표 2. 농업 & 2.1/2.2/2.3/2.4/2.5 & & \\
\hline 목표 3. 보건 & $\begin{array}{l}\text { 3.1/3.2/3.3/3.4/3.7/3.8 } \\
\text { 3.a/3.b/3.c/3.d }\end{array}$ & & \\
\hline 목표 4. 교육 & $\begin{array}{l}\text { 4.1/4.2/4.3/4.4/4.5/4.6/ } \\
\text { 4.7/4.a/4.b/4.c }\end{array}$ & & \\
\hline 목표 5. 젠더 & $\begin{array}{l}\text { 5.1/5.2/5.3/5.4/5.5/5.6/5. } \\
\text { a/5.b/5.c }\end{array}$ & & \\
\hline 목표 6. 식수/위생 & 6.1/6.2/6.4/6.6/6.b & & \\
\hline 목표 7.에너지 & 7.1/7.2/7.3/7.b & & \\
\hline 목표 8. 경제/고용 & 8.1/8.2/8.3/8.7/8.10/8.a & & \\
\hline
\end{tabular}

8) [10.c 2030년까지 이주 노동자의 송금 수수료 $3 \%$ 이내로 경감 및 $5 \%$ 이상의 송금 코리더 철폐] 등과 같이 KOICA 가 이행할 수 없는 과제들은 제외하였다. 


\begin{tabular}{l|l|l|l}
\hline 목표 9.인프라 & 9.5 & $9.1 / 9.4 / 9 . a / 9 . c$ & 9.3 \\
\hline 목표 10.불평등 & & & $10 . \mathrm{b}$ \\
\hline 목표 11. 도시 & $11.5 / 11.6$ & $11.1 / 11.2 / 11.3 / 11 . \mathrm{c}$ & \\
\hline 목표 12. 생산/소비 & $12.1 / 12.3 / 12 . a$ & & \\
\hline 목표 13. 기후변화 & $13 . \mathrm{b}$ & & \\
\hline 목표 14. 해양환경 & & 목표 14 전체 & \\
\hline 목표 15. 육상환경 & & 목표 15 전체 & \\
\hline 목표 16. 거버넌스 & 16.6 & 16.5 & $17.3 / 17.16 / 17.17$ \\
\hline 목표 17. 이행수단 & $17.1 / 17.6 / 17.8 / 17.9 / 17.18$ & & \\
\hline
\end{tabular}

출처: 저자작성

〈Box 10〉 선진국 개발협력 해당 SDGs 이행과업별 target 분류 기준

- 이행과업: MDGs 이행과정에서의 경험을 바탕으로 현재 진행하고 있거나 즉시 이행이 가능한 세부목표

- 중장기 목표 과업: 현재 이행하고 있지는 않으나 중장기적으로는 유상원조와의 협력관계 강화를 통한 인프라지 원 또는 도시화와 관련된 문제들에 대해 프로그램 접근을 시도할 수 있음

- 도전과제: 현재 이행을 위해서는 제도적인 보완이 필요한 세부목표임

출처: 저자작성

위의 표에서 알수 있듯이 각 세부목표들간에는 실제 KOICA의 이행가능성 및 이행 용이성이 명확 치 않아 그 구분이 모호한 경우가 많다. 따라서 본 부분에서는 우선 아래 표와 같이 일정한 분류기준 에 따라 세부목표들을 세분화하는 작업을 시도하였으나, 이는 관점에 따라 상이할 수 있음을 밝힌다. 이러한 고려사항을 바탕으로 볼 때 먼저 이행과업 부분에는 교육, 보건 등 KOICA의 주요 전략분야가 해당된다. 현재 $\mathrm{KOICA}$ 가 중장기 전략을 수립하고 있는 5 대 주요 이슈 및 범분야 이슈의 경우, 현재 기존의 MDGs 이행과정에서의 경험 및 노하우를 바탕으로 하여, SDGs 세부목표의 즉시 이행이 가능 하다.

그리고 중장기 목표 과업에는 SDG 14 와 15 등 자연자원의 보호와 활용에 관한 영역을 $\mathrm{KOICA}$ 의 과업에 포함하여 이행할지에 대한 정책적인 결정이 필요한 부분이 해당된다. 마지막으로 도전과제 의 경우는 SDG 17.3 (다양한 방식을 통해 추가적인 재원을 동원)과 같이, OECD DAC의 TOSSD 논 의와 더불어 2015년 이후 개발협력에 있어 주요한 이슈이나 현재 KOICA의 법제상 불가능한 영역이 
있고, 법적으로 불가능하지는 않으나 정치적인 결정이 필요한 부분이 있다. 또한 SDG 17.2(선진국 은 개발도상국에 지원하기로 약정한 ODA/GNI $0.7 \%$ 를 달성하는 등 ODA 활동을 완수해야하며, 이 중 0.15-0.2\%는 최빈국에 제공), 17.4 (부채조달, 채무탕감, 부채조정 등을 위한 공조정책을 통해 개 도국의 장기부채지속성 확보를 지원하고 부채고통을 경감하는 차원에서 고채무국의 외채문제 고려), 17.14(지속가능개발을 위한 정책일관성 향상) 등과 같이 KOICA 만의 과제가 아니라 개발협력과 관련 된 다양한 부처와의 협의를 통해 국가적 차원에서 접근해야 하는 과제들도 해당된다.

\section{3. 세부전략과 이행메커니즘의 조화방안}

이렇듯 $\mathrm{KOICA}$ 는 중장기 전략 내에 전략과 이행메커니즘의 적절한 조화를 통해 SDGs의 효과적 인 달성에 기여하고자 한다. 이를 위해 $\mathrm{KOICA}$ 중장기 전략 내에 각 전략과제별 실행과제 및 총 90 건에 다르는 세부과제를 설정하고 각 부서별로 주 담당 및 협업을 통해 실행할 계획이며, 이를 통해 $\mathrm{KOICA}$ 중장기 전략 전체에 대한 SDGs 주류화를 이룸으로써 궁극적으로 KOICA 5대 브랜드 프로그 램의 각 주제를 효과적으로 이행하고자 한다.

$\mathrm{KOICA}$ 의 5 대 브랜드 프로그램은 $\mathrm{KOICA}$ 의 중장기전략 추진과제 전반을 포괄하는 종합적인 이니 셔티브로, 각 분야별 중기전략을 비롯한 KOICA 3 대 핵심전략을 바탕으로 본 이니셔티브에 대한 전략 이 수립되었으나, 이러한 이니셔티브의 효과적인 이행을 위해서는 기타 다양한 이행메커니즘들의 활 발한 운영이 요구된다.

이로 인해 $\mathrm{KOICA}$ 는 중장기 전략 내에 전략과 이행메커니즘의 적절한 조화를 통해 SDGs의 효과 적인 달성에 기여하고자 한다. 이를 위해 KOICA 중장기 전략 내에 각 전략과제별 실행과제 및 총 90 건에 다다르는 세부과제를 설정하고 각 부서별로 주 담당 및 협업을 통해 실행할 계획이다.

따라서 $\mathrm{KOICA}$ 는 중장기전략 내에 수립 중인 각 분야별 중기 전략과 이행메커니즘들간의 상호긴 밀한 접목을 통해 SDGs의 주류화를 확산시킴으로써 5 대 이니셔티브를 성공적으로 이행할 수 있을 것이다. 이러한 과정에서 지속적으로 노력해나감으로써 KOICA는 향후 SDGs 달성에 기여해가고자 한다. 


\section{V. 결론: KOICA 중장기 전략 기대효과 및 추가 논의 필요성}

Post-2015 시대를 이끌어갈 SDGs는 보편성, 포용성, 평등을 기본가치로 하면서 현재 지구촌 전 체가 직면한 도전과제들을 광범위하게 포함하고 있다고 할 수 있다. 특히 사회발전, 경제성장 뿐만 아니라 환경보존이라는 조금은 상충되는 요소들간의 조화를 이루는 작업이 강조되고 있으며, 이를 위해서는 우리나라를 비롯한 국제사회는 각자 보다 효과적인 SDGs 이행방안을 마련하는 동시에 국 제사회의 연대를 통해 보다 창의적이고 혁신적인 대응방안을 강구해나가기 위해 부단히 노력하는 중 이다.

이러한 상황에서 $\mathrm{KOICA}$ 는 새로운 $\mathrm{SDGs}$ 체제 이행을 위한 국제사회의 환경 변화와, 이로 인한 우리나라 정부의 대응방향 등을 종합적으로 반영한 기관 전략을 수립하기 위해 지난 3 월 종합적인 'KOICA 중장기전략'을 수립하였으며, SDGs의 효과적인 이행을 위해 전략 내 KOICA 5 대 이니셔티 브를 발촉하였다. 아울러 중장기 전략 내 내년 2016년 6월까지 최종 완료될 예정인 5대 중점분야 및 3 대 범분야 각각에 대한 중기 전략 수립을 추진 중인 현재, $\mathrm{KOICA}$ 는 기관 내외적으로 다양한 의견을 수렴함으로써 보다 완성도 높은 중장기전략을 수립하고자 한다. 이와 동시에 중장기 전략상의 다양한 이행메커니즘에 대한 SDGs 주류화 작업을 함으로써, 향후 5 대 이니셔티브를 효과적으로 달성할 수 있는 이행수단으로서 역할할 수 있도록 해나갈 계획이다.

아울러 본래 $\mathrm{SDG}$ 는 범정부적인 task로서, 국내 이행 현황들을 정책적으로 접근하고 각 관련기 관들의 공동이행과 모니터링 및 보고를 진행해야할 부분이 많다. 하지만 국가 차원에서의 대응 전략 을 일시에 수립하는 작업은 결코 쉽지 않다. 따라서 우리나라 차원에서 보다 적극적이고 선제적으로 $\mathrm{SDGS}$ 에 대응해나가기 위해서는 먼저 하위 차원에서의 SDGs 타겟 및 지표 분석을 바탕으로 국가차 원의 상위 단계에서 SDGs 이행 가능 부분을 가늠하는 작업이 보다 수월할 것이다. 이러한 점에서, 주 요 원조실행기관인 KOICA는 이러한 작업의 시작점으로서, 최근 SDGs 타겟 및 지표들 중 KOICA 기 관차원에서 이행 가능 부분을 분류하는 작업에 착수하였다. 이에 내년 2016년 3월 SDGs 최종 지표가 확정되는 시점에 맞추어 오는 $\mathrm{KOICA}$ 의 주요 관련 타겟 및 지표분석을 완료하고, 오는 6월 각 분야별 중기전략까지 완성된다면, 이를 바탕으로 $\mathrm{KOICA}$ 는 내부 각 부처들 및 이해관계자들과 공유함으로써 $\mathrm{KOICA}$ 를 포함한 국내 차원에서의 이행방안에 대해서도 보다 세부적인 논의가 가능해질 것으로 기대 된다. 이렇게 될 때만이 $\mathrm{KOICA}$ 가 진정한 국제개발 플랫폼으로서의 제역할을 할 수 있을 것이다.

하지만 이러한 작업은 KOICA 혼자만이 할 수 있는 부분이 아니며, 관계 부처, NGO, 학계, 민간 기업 등 다양한 이해관계자가 한데 모여 포용적인 파트너십을 강화해나갈 때에 만이 가능하다. 따라 서 앞으로도 KOICA가 보다 다양한 참가자들의 의견을 바탕으로한 양질의 원조를 해나갈 수 있도록 
다양한 논의의 장을 이어나갈 계획이다. 따라서 국내의 많은 관계자들의 KOICA 내 SDGs 논의에 대 해 보다 많은 관심을 가지고 의견 및 지식, 경험 등을 적극적으로 공유한다면 KOICA가 보다 효과적 으로 SDGs전략을 이행해나갈 수 있을 것이다.

이러한 노력들을 통해 향후 KOICA가 '지구촌 행복시대를 위한 글로벌 플랫폼'으로서의 역할을 제 대로 수행함으로써 다양한 주체들이 KOICA라는 네트워크를 통하여 각자의 필요를 스스로 충족시켜 나갈 수 있는 사회를 구현하는데 기여할 수 있기를 바란다. 


\section{〈참고문헌〉}

김지현. 2014.12. "Post-2015 개발의제 동향연구1: SDGs 초안분석". 개발과 이슈 제19호. 성남: 한국국제협력단

박수영, 오수현. 2015. “제3차 개발재원총회와 아디스아바바 행동계획의 함의 분석”. 개발과 이슈 제 24 호. 성남: 한국국제협력단

외교부. 2015.09. “유엔개발정상회의(2015.9.25 27)". 서울: 외교부

한국국제협력단. 2015a. “KOICA 중장기 전략” 내부문서. 성남: 한국국제협력단 2015b. "2016년 KOICA대외무상원조 사업계획(안)" 내부문서. 성남: 한국국제

협력단

UN. 2015a. "Outcome document of the Third International Conference on Financing for Development: Addis Ababa Action Agenda". New York: United Nations, http://www. un.org/africarenewal/sites/www. un.org. africarenewal/files/ N1521991.pdf

2015b. "Resolution adopted by the General Assembly on 25 September 2015”. New York: United Nations, http://www.un.org/ga/search/view_doc. asp?symbol=A/RES/70/1\&Lang=E

2015c. "Adoption of the Paris Agreement". New York: United Nations, http://unfccc.int/resource/docs/2015/cop21/eng/109r01.pdf 